Stralberg, D., A. Camfield, M. Carlson, C. Lauzon, A. Westwood, N. K. S. Barker, S. J. Song. and F. K. A. Schmiegelow. 2018. Strategies for identifying priority areas for songbird conservation in Canada's boreal forest. Avian Conservation and Ecology 13(2):12. https://doi.org/10.5751/ ACE-01303-130212

Copyright $(\mathcal{} 2018$ by the author(s). Published here under license by the Resilience Alliance.

Research Paper, part of a Special Feature on Conservation of Boreal Birds

\title{
Strategies for identifying priority areas for songbird conservation in Canada's boreal forest
}

\author{
Diana Stralberg ${ }^{1,2}$, Alaine F. Camfield ${ }^{3}$, Matthew Carlson ${ }^{4}$, Christopher Lauzon ${ }^{3}$, Alana Westwood ${ }^{1,5}$, Nicole K. S. Barker ${ }^{1}$, \\ Samantha J. Song ${ }^{6}$ and Fiona K. A. Schmiegelow ${ }^{1,2,7}$ \\ ${ }^{1}$ Boreal Avian Modelling Project, University of Alberta, Edmonton, AB, Canada, ${ }^{2}$ University of Alberta, Renewable Resources \\ Department, Edmonton, AB, Canada, ${ }^{3}$ Canadian Wildlife Service - Environment and Climate Change Canada, Gatineau, QC, \\ Canada, ${ }^{4}$ ALCES Group, Ottawa, ON Canada, ${ }^{5}$ Dalhousie University, Department of Biology, Halifax, NS, Canada, ${ }^{6}$ Canadian \\ Wildlife Service - Prairie Region, Environment and Climate Change Canada, Edmonton, AB, Canada, ${ }^{7}$ Yukon Research Centre, \\ Whitehorse, YT, Canada
}

\begin{abstract}
Canada's boreal forest region is among the most extensive and largely intact ecosystems on earth, but has experienced rapid industrial development in the last half-century. Calls for urgent conservation action have been prompted by the increasing pace of development and declines in biodiversity, including songbirds. To assist conservation decision making, we introduce a framework to facilitate selection of the highest priority areas for a given conservation objective. We varied six key decision points representing possible constraints or a priori conservation factors: (1) prioritization metric (species representation vs. diversity), (2) geographic stratification, (3) degree of anthropogenic disturbance, (4) species' conservation status, (5) species' ecological association, and (6) climate-change and uncertainty discounting. Using the Zonation conservation planning tool, we evaluated landbird conservation priorities across 128 scenarios for 63 passerine species based on current and projected future density predictions. We compared Zonation land rankings across scenarios with respect to consistency, efficiency (additive and proportional conservation value per unit area), and the relative contributions of each of the six factors of interest. We found large differences between solutions depending on constraints and conservation objectives, and relatively low conservation efficiency overall, with the largest gains in overall conservation value observed in areas ranging from $0.31-0.56$ of the study region. This reflects the large range of conservation opportunities still present in the Canadian boreal region, and the widely dispersed nature of landbird distributions, which results in high substitutability among similar areas. However, we did find increasing consistency among solutions as multiple constraints were considered. In particular, stratifying solutions geographically resulted in more consistent priorities, although at the expense of efficiency. Other constraints, including climate change, disturbance- and uncertainty-discounting, and the selection and weighting of species, helped to further focus priorities. Although no single scenario can be viewed as prescriptive, we provide a roadmap for prioritizing boreal songbird conservation efforts across multiple conservation objectives.
\end{abstract}

\section{Stratégies visant l'identification d'endroits prioritaires pour la conservation de passereaux en forêt boréale canadienne}

RÉSUMÉ. La région de la forêt boréale du Canada figure parmi les écosystèmes les plus vastes et les plus intacts de la planète, mais elle a connu une exploitation industrielle rapide au cours du dernier demi-siècle. Le rythme croissant d'exploitation et de diminution de la biodiversité, dont les oiseaux chanteurs, a mené à des appels urgents à l'action pour la conservation. Pour guider la prise de décision en conservation, nous proposons un cadre facilitant la sélection des endroits prioritaires les plus importants pour un objectif de conservation donné. Nous avons fait varier six points clés de décision représentant des contraintes possibles ou des facteurs de conservation a priori : (1) paramètre de priorisation (représentation de l'espèce c. sa diversité), (2) stratification géographique, (3) degré de dérangement humain, (4) statut de conservation de l'espèce, (5) association écologique de l'espèce, et (6) changement climatique et réduction de l'incertitude. Au moyen du logiciel de planification de la conservation Zonation, nous avons évalué les priorités de conservation d'oiseaux terrestres parmi 128 scénarios pour 63 espèces de passereaux, en nous fondant sur les densités actuelles et des prédictions de densités futures. Nous avons comparé la priorisation terrestre des scénarios faite par Zonation selon la cohérence, l'efficacité (valeur de conservation par unité additive et proportionnelle) et la contribution relative de chacun des six facteurs d'intérêt. Nous avons obtenu de grandes différences entre les solutions en fonction des contraintes et des objectifs de conservation, et une efficacité de conservation relativement faible dans l'ensemble, les gains les plus grands de la valeur globale de conservation observés dans divers endroits allant de 0,31 à 0,56 de la région d'étude. Ce résultat reflète la gamme étendue d'occasions de conservation encore présentes dans la région boréale canadienne et le caractère fort dispersé de la répartition des oiseaux terrestres, résultant en un potentiel élevé de substitution parmi les endroits similaires. Toutefois, nous avons trouvé une cohérence croissante parmi les solutions parce que de

Address of Correspondent: Diana Stralberg, University of Alberta, Renewable Resources Department, 751 General Services Building, Edmonton, Alberta, T6G 2H1, diana.stralberg@ualberta.ca 
multiples contraintes ont été considérées. Plus particulièrement, la stratification géographique des solutions menait à des priorités plus cohérentes, mais aux dépens de l'efficacité. D'autres contraintes, dont le changement climatique, la réduction du dérangement et de l'incertitude, et la sélection et la pondération des espèces, ont contribué à préciser davantage les priorités. Même si aucun des scénarios ne peut être qualifié de prescriptif, nous fournissons un cadre destiné à prioriser les efforts de conservation des oiseaux chanteurs boréaux en présence de nombreux objectifs de conservation.

Key Words: climate change; conservation prioritization; passerine birds; reserve design; Zonation

\section{INTRODUCTION}

The boreal forest of North America is recognized globally for its contribution to wildlife and ecosystem values (Bradshaw et al. 2009, Carlson et al. 2009), and especially as a region of hemispheric significance for migratory birds (Wells and Blancher 2011). Among the most intact ecosystems remaining on earth, the region has experienced rapid industrial development in the last half-century, prompting urgent calls for conservation action (Bradshaw et al. 2009, Schindler and Lee 2010). An ambitious conservation target of $50 \%$ of the land area has been put forward by conservationists (Badiou et al. 2013), largely in response to the purported failure of lower percentage targets to adequately protect viable populations elsewhere (Solomon et al. 2003, Svancara et al. 2005), and in recognition of the conservation opportunities that remain in the largely intact boreal region (Dinerstein et al. 2017). Meanwhile, Canada and other signatories to the Convention on Biodiversity have committed to conserving $17 \%$ of the terrestrial land base in protected areas by 2020 as part of the Aichi Biodiversity Targets (http://www.cbd.int/sp/targets). Although scientific justification for specific percentage targets has been difficult to establish (Tear et al. 2005, Wiersma and Nudds 2006, Wiersma et al. 2017), large-scale conservation and management efforts are presumed necessary to maintain intact hydrological and natural disturbance processes (Pickett and Thompson 1978, Leroux et al. 2007), and to accommodate species' distributional responses to climate change (Krawchuk et al. 2012, Powers et al. 2017, Magness et al. 2018).

Passerine birds (hereafter songbirds) constitute a major component of boreal biodiversity, with $\sim 80 \%$ of species migrating to boreal breeding grounds from other portions of the western hemisphere (Wells and Blancher 2011). Yet geographic conservation priorities have not been identified for this taxonomic group. A diversity of conservation objectives, planning processes, and participants, combined with the vast size of the boreal region, limits the potential for a single, one-size-fits-all, boreal-wide conservation plan. Such large-scale, complex conservation problems can nevertheless benefit from spatial conservation prioritization through the use of site selection or reserve selection algorithms (Csuti et al. 1997, Pressey et al. 1997, Kukkala and Moilanen 2013), which simultaneously consider multiple conservation objectives and constraints to identify efficient and complementary conservation priorities across a study region. Typically, the identification of priority areas is based on empirical information about the distribution and/or abundance of species of interest, and constraints include management factors such as cost and existing land uses (Moilanen 2007). Species-focused conservation prioritization efforts in many regions have focused on the identification of hotspots of rarity, endemism, diversity, and abundance (e.g., Margules et al. 1988, Williams et al. 1996, Early et al. 2008). Boreal birds, however, tend to be broadly distributed across the continent at low densities (Slattery et al.
2011, Wells and Blancher 2011, Barker et al. 2014), with low levels of endemism and rarity (Leroux and Schmiegelow 2007). Songbirds and other landbirds, in particular, exhibit territorial behavior on their breeding grounds and tend to be dispersed across the landscape, rather than clustered in diversity and abundance hotspots. This creates a unique challenge for prioritizing conservation action in the boreal forest region (Carlson 2015). Furthermore, although the boreal region's intactness offers an immense conservation opportunity (Powers et al. 2013), it also presents a context for prioritization that differs from more populated regions where there is a need to identify the optimal configuration of specific habitats to balance land use pressures (Moilanen et al. 2011) or maintain connectivity across developed landscapes (Lehtomäki et al. 2009, Pouzols and Moilanen 2014).

Estimating the abundance and distribution of boreal songbirds is difficult because of the vastness and inaccessibility of the region. However, recent data compilations (Cumming et al. 2010, Barker et al. 2015), combined with advances in machine learning (Elith et al. 2006, 2008) and detectability corrections (Sólymos et al. 2013), have enabled the development of increasingly sophisticated species distribution and density models for boreal songbirds (Stralberg et al. 2015a). The resulting spatially explicit population density estimates can facilitate data-driven conservation planning. Density has demonstrated better performance than other metrics of species distribution (such as probability of occurrence or habitat suitability) for identifying priority conservation areas (Veloz et al. 2015). Here we applied Zonation (Moilanen 2007) to identify priority conservation areas for boreal songbirds. Zonation is among the most widely used prioritization tools, and was well-suited to the task at hand because of its ability to process large volumes of spatial data to rank individual cells across the study region according to their combined conservation value for multiple species. This ranking may be used to identify the best conservation solution for any given proportion of Canada's boreal region without setting a priori targets.

The best solution to a given conservation planning problem can, however, vary widely according to different conservation criteria. To meet specific conservation objectives in realms such as protected areas planning, species-at-risk recovery, habitat restoration, or long-term monitoring, decision makers need to select their criteria thoughtfully. Here we introduce a framework to aid in this process by assessing the most appropriate scenario formulation for different combinations of criteria (Fig. 1). We identified six key decision points with a total of 128 unique scenario combinations. The decision points included two primary factors that we hypothesized would result in fundamentally different solutions: (1) prioritization metric (species representation or diversity); and (2) geographic stratification (boreal-wide or by subregion). These factors were considered primary in that they 
Fig. 1. Scenario roadmap with example hypothetical conservation objectives. For example, if the objective is to identify new potential protected areas with high boreal bird diversity (black), one might select a boreal-wide scenario that emphasizes species diversity, discounts areas of higher uncertainty, includes both current and projected midcentury distributions, weights all species equally, and considers all priority songbird species, leading one to select scenario 106 (see Table A1.1 for definitions). Conversely, if the objective was regional habitat reclamation or restoration (medium green), one might select a geographically stratified scenario that does not discount for disturbance, e.g., scenario 103. Theoretically, each of the 128 scenarios we generated could be the desired scenario for a different conservation objective. $\mathrm{BCR}=$ bird conservation region.

\section{SAMPLE CONSERVATION OBJECTIVES}
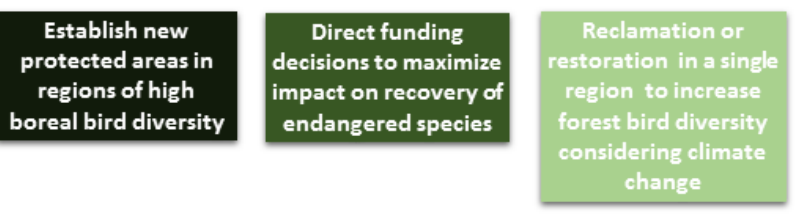

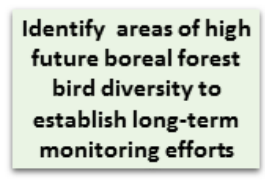

\section{ZONATION MODELSCENARIO DECISIONTREE}

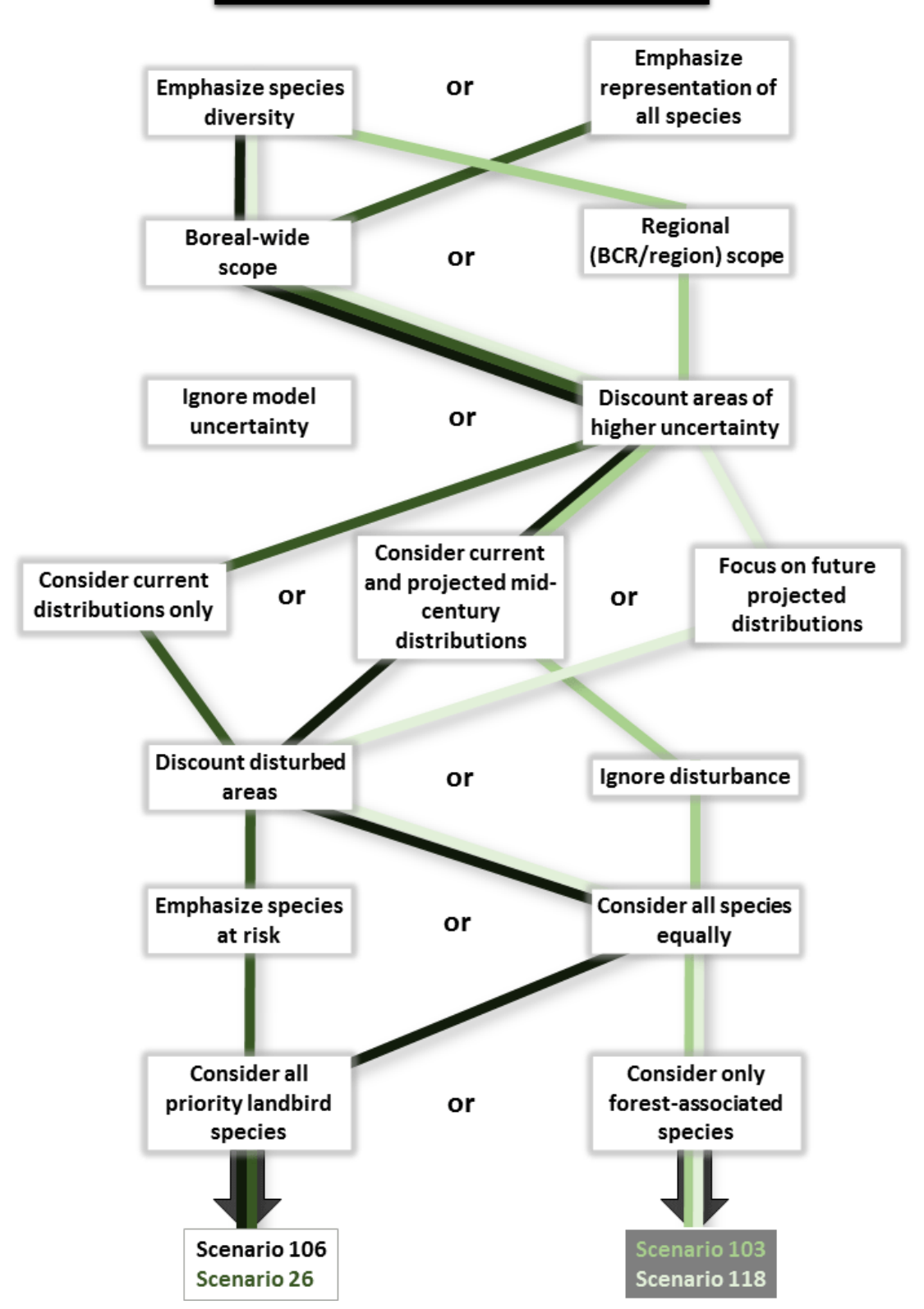


determined to what extent priority areas would be distributed across geographic regions and species' ranges.

We also considered four additional factors that we expected could result in important local differences in conservation priorities: (3) degree of anthropogenic disturbance, (4) species' conservation status, (5) species' ecological association (forest-associated species vs. all songbirds), and (6) climate change and prediction uncertainty. We expected that filtering species subsets based on conservation status and ecological association would prioritize different areas based on variation among species' distributions. We also expected that incorporating anthropogenic disturbance and model uncertainty as constraints would tend to shift prioritization away from areas with more land use, which tend to be in the south, and lower sampling effort, which tend to be in the north, respectively. Finally, we anticipated that including climate change would shift conservation objectives and resulting priorities northward, as has previously been demonstrated (Stralberg et al. 2015b).

Using this a priori hierarchy, we analyzed similarities and differences among scenarios, seeking to answer the following questions:

1. Are certain areas consistently ranked highly in terms of bird conservation value across scenarios?

2. How do solutions for each combination of primary factors differ?

3. How consistent are solutions within each combination of primary factors?

4. What is the relative influence of each factor on solutions, both overall and sequentially?

5. Which scenarios and proportional conservation targets are most efficient in terms of bird conservation value per unit area?

We focused here on evaluating the efficiency of solutions for each scenario (Pressey and Nicholls 1989, Kukkala and Moilanen 2013), rather than determining how much area should be protected, i.e., conservation adequacy (Kukkala and Moilanen 2013) or effectiveness (Rodrigues et al. 1999). This was partly a function of the large study region and the relatively few and wideranging species under consideration, such that the mere representation of all target species is easily achieved in a small fraction of the study region (Wiersma and Sleep 2018). We also did not have adequate data to evaluate population viability under different levels of conservation for multiple species (Rondinini and Chiozza 2010). Finally, we assumed that policy-driven conservation objectives would be developed independently from our efforts, but could be informed by this data-driven approach.

\section{METHODS}

\section{Study region and input data}

Within the boreal forest region of Canada, our $\sim 5.2$ million $\mathrm{km}^{2}$ study region consisted of bird conservation regions (BCRs) 4, 6, 7, and 8 (Bird Studies Canada and NABCI 2014), which coincide with boreal and taiga level III ecoregions as defined by the Commission for Environmental Cooperation (CEC 1997; Fig. 2). For purposes of geographic stratification we also recognized subregions within each BCR, as defined by either provincial boundaries or Canadian Wildlife Service (Environment and Climate Change Canada [CWS-ECCC]) management jurisdictions,

Fig. 2. Study region map. Bird conservation subregions outlined in dark gray and cross-hatched. NR = Northern Region; $\mathrm{PR}=$ Prairie Region. $\mathrm{BC}=$ British Columbia; $\mathrm{ON}=$ Ontario; $\mathrm{QC}=$ Québec; NL = Newfoundland and Labrador. Brandt's (2009) boreal region shaded light gray.

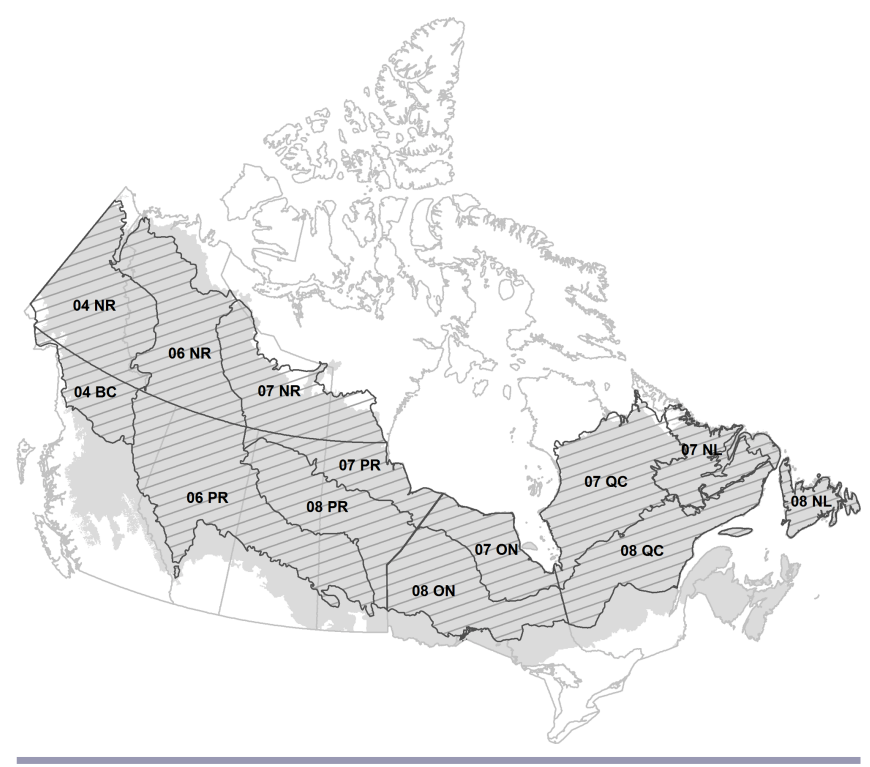

determined by latitudinal thresholds ( 60 th parallel). This resulted in a total of 13 administrative units.

In Zonation, the species or ecological features to be conserved are termed input features, which in our case was a combined list of 63 passerine species that had been identified as priority species according to at least one boreal BCR strategy document (https:// www.canada.ca/en/environment-climate-change/services/migratorybird-conservation/regions-strategies.html). Input population density rasters for these species were based on predictions from boosted regression tree models applied to the Boreal Avian Modelling Project's (BAM) dataset of point-count locations across North America (Cumming et al. 2010). The data were derived from a variety of projects, and harmonized for survey method and detectability using statistical offsets (Sólymos et al. 2013, Barker et al. 2015). Species distribution modeling was used to predict densities at a $4-\mathrm{km}$ resolution across the study region under both current and future climate scenarios (Stralberg et al. 2015a). Predictions were averaged across multiple data samples, variable sets, and global climate models (Stralberg et al. 2015a). We considered three separate sets of raster input features: (1) current density; (2) future (2041-2070) projected density; and (3) current and future projected densities.

Because of the vast extent of the boreal forest, and the relatively small area that has been empirically surveyed, predicted densities are less accurate in areas containing fewer point-count samples. To account for this, we generated estimates of prediction uncertainty for each species, calculated as the standard deviation across multiple data samples, variable sets, and global climate models (Fig. 3a). For some scenarios, these 4-km rasters were used to discount the value of undersampled regions using Zonation's distribution discounting option. This necessarily resulted in lower 
Fig. 3. Combined disturbance and uncertainty discounting maps. (a) Mean uncertainty, i.e., coefficient of variation of density estimates averaged across 63 species (illustrative only; individual species' standard deviation layers used in analysis); (b) current anthropogenic disturbance proportion.

\section{(a) mean uncertainty}

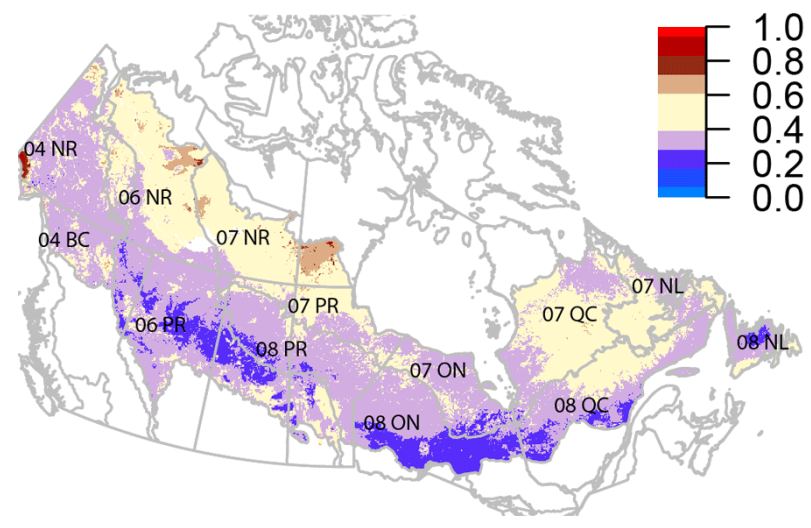

(b) disturbance

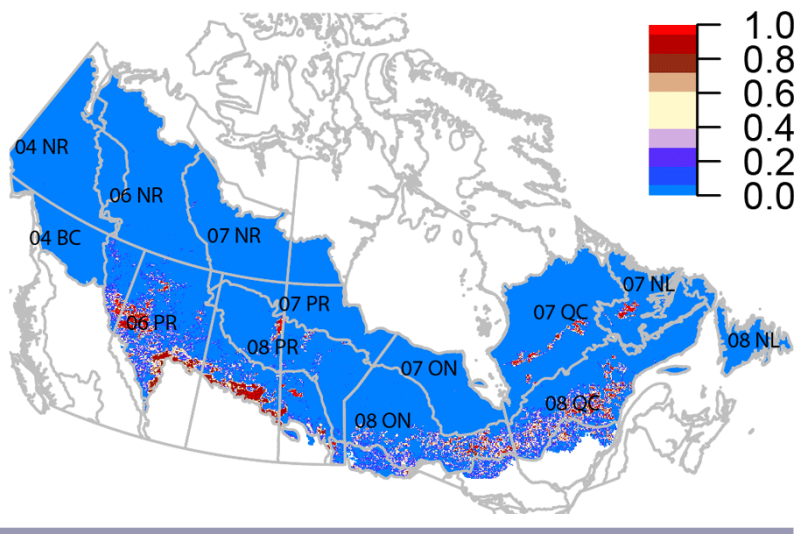

values for future density projections, compared to current density predictions.

For some scenarios, we also discounted cells based on the amount of anthropogenic disturbance they contained. For this purpose we generated a raster representing anthropogenic disturbance as a proportion of the area disturbed within each 4-km grid cell. Given that no single anthropogenic disturbance layer covered our entire study region, we merged a Landsat-based industrial development footprint layer (Pasher et al. 2013) with a Landsatbased 2001-2014 forest loss layer (Hansen et al. 2013), as well as urban and agricultural land-use classes from a 2005 MODISbased landcover map (http://www.cec.org/naatlas). Because the forest loss layer includes natural disturbance, we removed areas of large fires (Canadian Forest Service 2015) from the estimates (Fig. 3b) to limit the disturbance layer to anthropogenic impacts.

\section{Zonation analysis}

To compare the influence of constraints and a priori conservation objectives, and to evaluate commonalities among them, we identified six factors representing key decision-points (Table 1), for which all possible combinations resulted in 128 unique scenarios (Table A1.1).

The Zonation software (Moilanen et al. 2011) ranks the value of each cell based on user-defined criteria, and iteratively removes cells with the lowest proportional value across all criteria. A low number of cells (10) was removed during each iteration to improve optimality of solutions. After each removal, proportional conservation values for each cell are recalculated to reflect changes in remaining overall conservation value. After all cells have been removed, we are left with a ranking of all cells, with cells removed last having the highest priority for the conservation criteria. We used two different cell-removal rules to compare prioritization metrics (Factor 1): species representation (using core-area Zonation, which emphasizes rare or heavily weighted species to maximize core habitat for these species) and species diversity (using an additive benefit function, which favors areas of high diversity across all species). For species diversity, we used a power function exponent of 0.25 in the additive benefit function to allow a relatively rapid accumulation of species' conservation value with each additional grid cell (Moilanen et al. 2014). This translates

Table 1. Factors manipulated to develop alternative scenarios for Zonation analysis. Each of the 128 scenarios evaluated (Table A1.1) represents a unique combination of factors.

\begin{tabular}{|c|c|c|}
\hline $\begin{array}{l}\text { Nu- } \\
\text { mber }\end{array}$ & Factor & Alternatives \\
\hline 1 & $\begin{array}{l}\text { Prioritization } \\
\text { metric }\end{array}$ & $\begin{array}{l}0=\text { species representation (core area Zonation) } \\
1=\text { species diversity (additive benefit function) }\end{array}$ \\
\hline 2 & $\begin{array}{l}\text { Geographic } \\
\text { stratification }\end{array}$ & $\begin{array}{l}0=\text { combined conservation priorities across } \\
\text { entire study area } \\
1=\text { separate conservation priorities by bird } \\
\text { conservation subregions (based on separate } \\
\text { priority species lists for each bird conservation } \\
\text { subregion) }\end{array}$ \\
\hline 3 & Disturbance & $\begin{array}{l}0=\text { no discounting by anthropogenic disturbance } \\
1=\text { discounted by anthropogenic disturbance }\end{array}$ \\
\hline 4 & $\begin{array}{l}\text { Conservation } \\
\text { Status }\end{array}$ & $\begin{array}{l}0=\text { all species weighted equally } \\
1=\text { priority species receive higher weights (Table } \\
\text { A1.2) }\end{array}$ \\
\hline 5 & $\begin{array}{l}\text { Ecological } \\
\text { association }\end{array}$ & $\begin{array}{l}0=\text { include all species } \\
1=\text { include only forest-associated boreal species } \\
(\text { Table A1.2) }\end{array}$ \\
\hline 6 & $\begin{array}{l}\text { Prediction } \\
\text { uncertainty } \\
\text { and climate } \\
\text { change }\end{array}$ & $\begin{array}{l}0=\text { current distribution only, certainty not } \\
\text { included } \\
1=\text { current distribution, discounted by } \\
\text { uncertainty } \\
2=\text { current and future distributions, uncertainty- } \\
\text { discounted } \\
3=\text { future distribution, uncertainty-discounted }\end{array}$ \\
\hline
\end{tabular}

into relatively high species interchangeability, in contrast with the zero interchangeability provided by core-area Zonation.

We used Zonation's administrative units feature to impose geographic stratification (Factor 2) of conservation priorities. For BCR-stratified scenarios (vs. boreal-wide), we separately identified conservation priorities for each bird conservation subregion based on its identified priority species (Table A1.2). To 
reflect newly created CWS-ECCC jurisdictions for BCRs 6 and 7, we used the BCR 4 priority species list for the northern subregions and kept existing priority species lists for the southern portions. For BCR 4, we used the BCR 6 priority species list for the southern subregion and kept the existing priority species list for the northern portion. Each subregion was weighted equally to ensure that priority areas were distributed across subregions in proportion to their area. These scenarios were intended to be used in a different planning context than the boreal-wide scenarios; namely, the development of bird conservation subregion-level conservation strategies.

Discounting by the degree of anthropogenic disturbance (Factor 3) was implemented using Zonation's info-gap weighting option using the merged anthropogenic disturbance layer. Although we recognize that species are differentially affected by different levels and types of disturbance, we treated all forms of disturbance as being equal for all bird species. We used a discounting factor (alpha weight) of one to encourage strong uncertainty and disturbance discounting, such that cells that were $x \%$ disturbed had $(1-x) \%$ of the value of undisturbed cells in disturbancediscounted scenarios, all other factors equal.

To allow for differential species weights according to species' conservation status (Factor 4), species were either all weighted equally, or weighted according to conservation status; species weights were constant across bird conservation subregions. Species listed on Schedule 1 of the Canadian Species at Risk Act (SARA; Canada Warbler, Cardellina canadensis; Olive-sided Flycatcher, Contopus cooperi; and Rusty Blackbird, Euphagus carolinus) were assigned a weight of 4 and species with Partners In Flight global population trend scores of 4 or 5, which have declined more than 15\% in recent decades (Rosenberg et al. 2016), were assigned weights of 2 and 3, respectively, with all other species given a weight of 1 (Table A1.2).

Species included based on ecological association (Factor 5) were either (a) all 63 priority species or (b) a subset of 46 forestassociated species (as defined by the Cornell Laboratory of Ornithology web site, http://allaboutbirds.org; Table A1.2).

To incorporate the expected influence of climate change and prediction uncertainty (Factor 6) on species' future distributions and densities, we compared three sets of input features based on models from Stralberg et al. (2015a): current predicted density/ distribution (63 species), future (2050s) projected density/ distribution (63 species), and both sets combined, with each time period treated as a separate species (126 species). For current densities, one set of 32 scenarios also included uncertainty discounting while the other did not. Both sets of climate-change scenarios (32 each) included uncertainty discounting. For uncertainty-discounted scenarios, the predicted density for a species at a given cell was discounted by the standard deviation of that prediction. Prior experimentation with different alpha values for uncertainty resulted in qualitatively similar spatial patterns; thus we chose the higher value (one) for greater contrast with undiscounted solutions.

\section{Posthoc analysis}

Zonation results or solutions were evaluated quantitatively based on mapped conservation priority ranks (cell values ranging from 0 -low to 1-high) and their variation among scenarios $(N=324,845$ cells). We averaged cell-level priority ranks across all 128 scenarios and among the 32 scenarios within each of the four combinations of primary factors (prioritization metric and geographic stratification), to identify the most highly ranked areas overall, and by objective, respectively (Question 1). We also evaluated consistency among scenarios (Question 2 ) by calculating the celllevel standard deviation of priority ranks overall and by combination of primary factors.

To evaluate the relative contributions of each factor, spatially and quantitatively (Questions 3 and 4), we mapped the differences and averaged the absolute differences between the rank of a given cell for a given scenario vs. the previous sequential scenario. Difference values ranged from -1 for a large decrease in conservation priority to 1 for a large increase. Baseline scenarios consisted of each of the four combinations of primary factors (representation-based / boreal-wide, diversity-based / borealwide, representation-based / BCR-stratified, and diversity-based / BCR-stratified). Scenario differences were then evaluated hierarchically in the order listed in Table 1 for each of these combinations of primary factors. That is, the additional contribution of each of the other four factors was mapped and quantified consecutively, with the previous scenario serving as the reference.

In addition, we quantified the overall influence of each of the six factors (Question 4) by calculating the mean and standard deviation of the cell-level differences between mean values for each pair of factor conditions across all scenarios combined. For example, to quantify the influence of geographic stratification, we calculated mean ranks for all of the BCR-stratified scenarios and compared them with mean ranks for all of the boreal-wide scenarios.

Finally, we evaluated the multispecies efficiency of each scenario across the entire range of conservation thresholds, i.e., top 1$100 \%$ of each solution (Question 5). We defined efficiency in terms of the average proportion of species conservation value conserved for a given proportion of the study region, $k$. Conservation value was assessed using Zonation's weighted range-size corrected richness index (WRSCR), a measure of abundance adjusted for species' weights and baseline abundance:

$$
\mathrm{WRSCR}_{k}=\sum_{i, j} w_{j} q_{i j}
$$

where $w_{j}$ is the weight of species $j$ and $q_{i j}$ is the fraction of the distribution of the species in grid cell $i$ for a given threshold $k$ (Moilanen et al. 2014). For each scenario, we plotted WRSCR across the entire range of thresholds, i.e., proportion of study region protected, and then calculated the area under the curve (AUC) of this performance curve to obtain a threshold independent assessment of efficiency, following similar methods by Summers et al. (2012). A higher AUC indicates more rapid increase in conservation value with area, i.e., greater efficiency. We also did this for individual species efficiency plots:

$$
\left(\Sigma_{i} q_{i}\right)
$$


Fig. 4. (a) Mean Zonation rank, indicating conservation value, across all 128 scenarios. Highest ranked areas are in dark blue; lowest ranked areas are in yellow. (b) Standard deviation of Zonation rank, indicating agreement in conservation value across scenarios. Highest variation in Zonation ranks is in red; lowest variation is in blue.

\section{(a) mean rank}

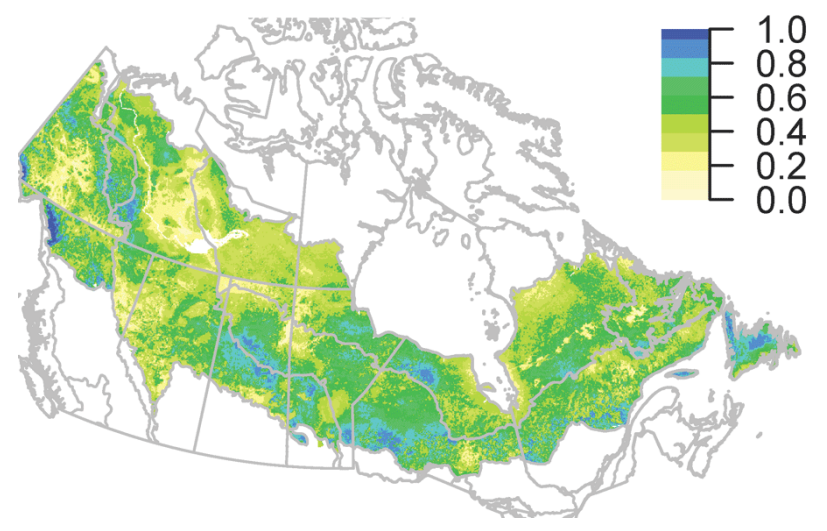

(b) SD rank

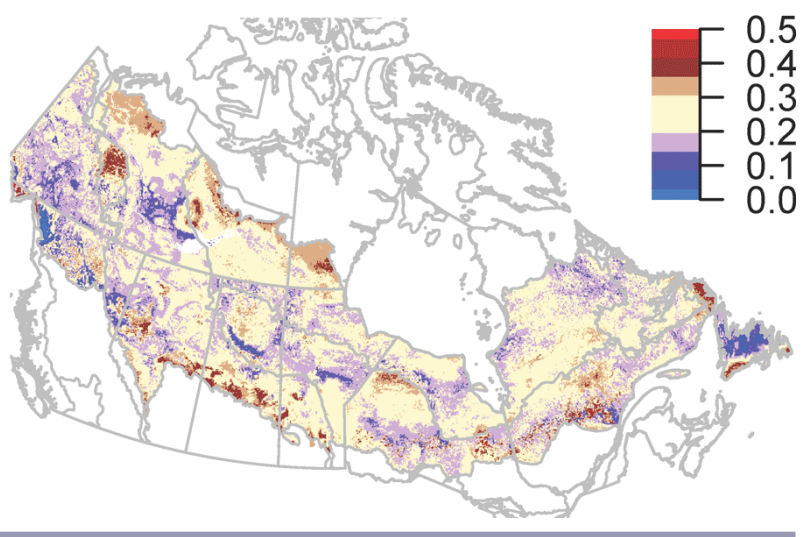

in order to assess the relative performance of each scenario for each species.

To compare multispecies efficiency across thresholds, we first identified the conservation threshold $k$ that resulted in the largest additive efficiency, i.e., the maximum difference between proportional bird conservation value, and the corresponding proportional land area, $A_{k}$ :

$$
\max \left(\mathrm{WRSCR}_{k}-A_{k}\right)
$$

We also plotted proportional efficiency, i.e., the ratio of conservation value to land area:

$$
\left(\mathrm{WRSCR}_{k} / A_{k}\right)
$$

which was a monotonically decreasing function by definition.

\section{RESULTS}

Results from all 128 scenarios are shown in Appendices 2 (64 representation-focused) and 3 (64 diversity-focused; see Table A1.1 for scenario numbers), with spatial data layers available at http://www.borealbirds.ca. Averaging across all scenarios, some of the most expansive areas with consistently high ranks were found in western BCR 4 (British Columbia and Northern Region), northwestern portions of BCR 6 (Northern Region), southern portions of BCR 8 (Prairie Region), eastern BCR 8 (Newfoundland and Labrador), and undisturbed pockets in southeastern BCR 6 (Prairie Region) and BCR 8 (Ontario and Québec; Fig. 4a). Areas with high variation in Zonation ranking did not coincide with highly ranked areas (Fig. 4b; Pearson $r$ $=-0.07)$.

Baseline solutions for the four combinations of primary factors (prioritization metric and geographic stratification) resulted in some differences in the locations of high value areas (Fig. 5). Boreal-wide and diversity-based scenarios tended to emphasize southern areas relative to bird conservation subregion-stratified and representation-based scenarios. Averaging across all scenarios within each combination of primary factors (Fig. 6), representation-based scenarios were generally more variable when compared to stratified and diversity-based scenarios (Fig. 7).

Using the boreal-wide representation-based scenario without further modification as a baseline (Fig. 8a), the proportional discounting of disturbed areas resulted in lower ranking of disturbed lands, particularly along southern boreal margins (Fig. $8 b)$. Subsequent incorporation of species weighting by conservation status resulted in higher ranking of certain northern boreal regions that were not otherwise highly ranked. Including only forest-associated species reduced rankings in northern (tundra) and southern (prairie) portions of the study region (Fig. 8c). Discounting of high-uncertainty areas reduced rankings along low-density southwestern margins in BCR 6 (Prairie Region), and also in northern BCR 7 (Québec and Ontario; Fig. $8 \mathrm{~d}$ ), while the incorporation of midcentury climate change projections resulted in higher rankings in northern- and midboreal regions (Fig. 8e). The incorporation of midcentury climate change projections resulted in the largest overall sequential difference, with a low standard deviation compared to the mean change (Table 2). The differences due to climate-change scenarios were also most consistent, with standard deviations less than the mean values.

The cumulative scenario incorporating all of these factors involved some cancellation of effects, primarily between species weightings, which reduced northern influence, and climate change, which increased it (Fig. 8f). Sequential differences for other prioritization/stratification combinations are shown in Table 2 and Figures A4.1-3.

For all four combinations of the two major factors, the incorporation of future climate change substantially altered Zonation results. When considering species' projected midcentury climate-based distributions in addition to current modeled distributions, we found major changes for both boreal-wide and bird conservation subregion-stratified scenarios (Figs. A5.1-2). 
Fig. 5. Priority rankings (a-d) and differences among them (e-h), based on four baseline scenarios: boreal-wide, diversity-focused (scenario 65), and representation-focused (scenario 1); and bird conservation subregion-stratified diversity-focused (scenario 67) and representation-focused (scenario 3). For panels a-d, highest Zonation ranks are in dark blue; lowest ranks are in yellow. For panels $\mathrm{e}-\mathrm{h}$, blue indicates higher rank than the comparison scenario; red indicates lower rank. BCR $=$ bird conservation region.

(a) boreal-wide, diversity-focused

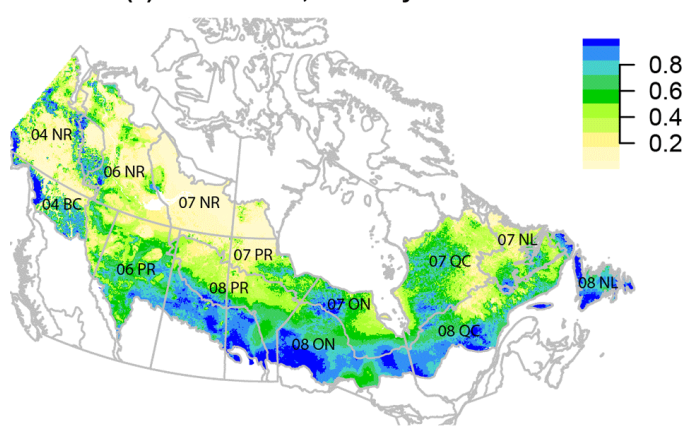

(c) BCR-stratified, diversity-focused

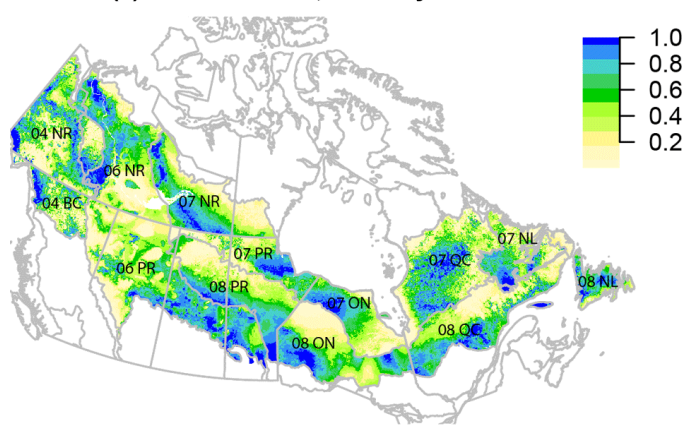

(e) boreal-wide, algorithm difference (b-a)

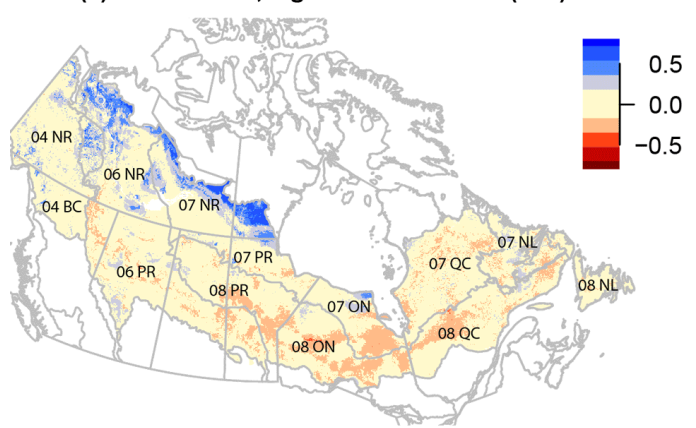

(g) BCR-stratified, algorithm difference (d-c)

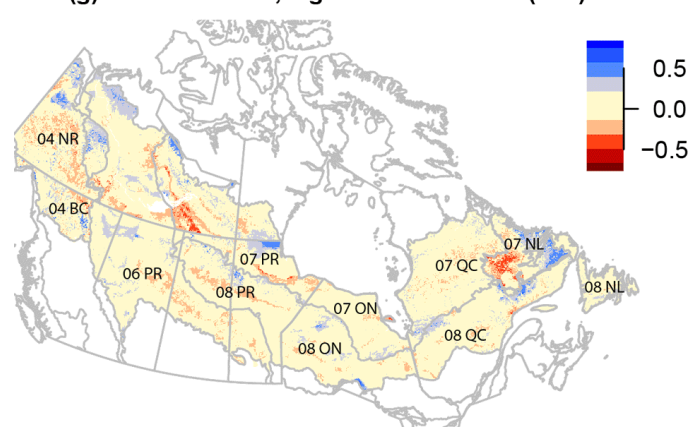

(b) boreal-wide, representation-focused

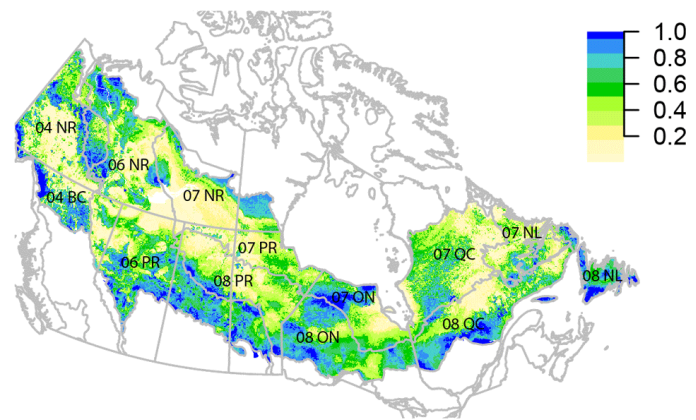

(d) BCR-stratified, representation-focused

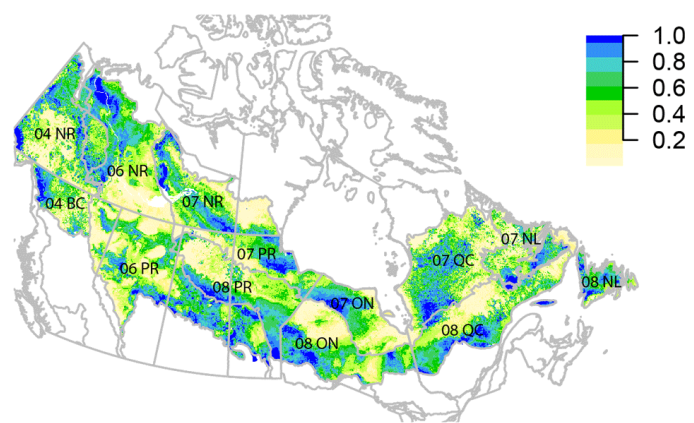

(f) diversity-focused, stratification difference (c-a)

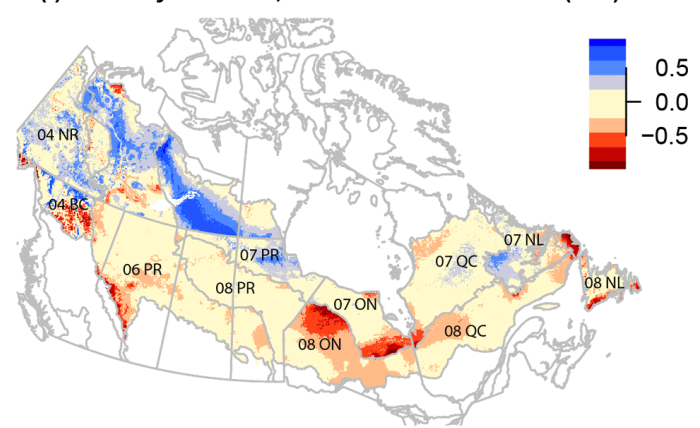

(h) representation-focused, stratification difference (d-b)

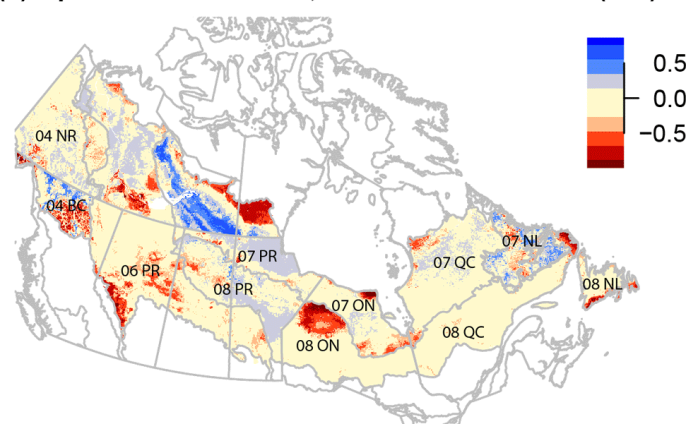


Table 2. Hierarchical contributions to conservation value of each scenario factor, grouped by prioritization algorithm and stratification. Values represent mean and standard deviation of pixel-level differences in priority ranks ranging from 0 to 1 . $\mathrm{BCR}=$ bird conservation region.

\begin{tabular}{|c|c|c|c|c|}
\hline Scenario factor & $\begin{array}{c}\text { Representation / Boreal- } \\
\text { wide }\end{array}$ & Diversity / Boreal-wide & $\begin{array}{c}\text { Representation / BCR- } \\
\text { stratified }\end{array}$ & Diversity / BCR-stratified \\
\hline Disturbance-discounted & $0.052( \pm 0.107)$ & $0.095( \pm 0.153)$ & $0.053( \pm 0.107)$ & $0.076( \pm 0.144)$ \\
\hline Species priority weighed & $0.147( \pm 0.126)$ & $0.056( \pm 0.050)$ & $0.000( \pm 0.000)$ & $0.000( \pm 0.000)$ \\
\hline Nonforest species excluded & $0.141( \pm 0.162)$ & $0.094( \pm 0.106)$ & $0.146( \pm 0.181)$ & $0.095( \pm 0.123)$ \\
\hline Uncertainty-discounted & $0.137( \pm 0.145)$ & $0.115( \pm 0.122)$ & $0.167( \pm 0.169)$ & $0.137( \pm 0.161)$ \\
\hline Climate-change modified (combo) & $0.206( \pm 0.180)$ & $0.140( \pm 0.127)$ & $0.222( \pm 0.203)$ & $0.188( \pm 0.179)$ \\
\hline Climate-change modified (future) & $0.210( \pm 0.185)$ & $0.170( \pm 0.159)$ & $0.240( \pm 0.204)$ & $0.150( \pm 0.143)$ \\
\hline
\end{tabular}

Fig. 6. Means for four groups of 32 scenarios: boreal-wide, diversity-focused (a) and representation-focused (b), and bird conservation subregion-stratified diversity-focused (c) and representation-focused (d). Highest Zonation ranks are in dark blue; lowest ranks are in yellow. BCR = bird conservation region.

(a) boreal-wide, diversity-focused

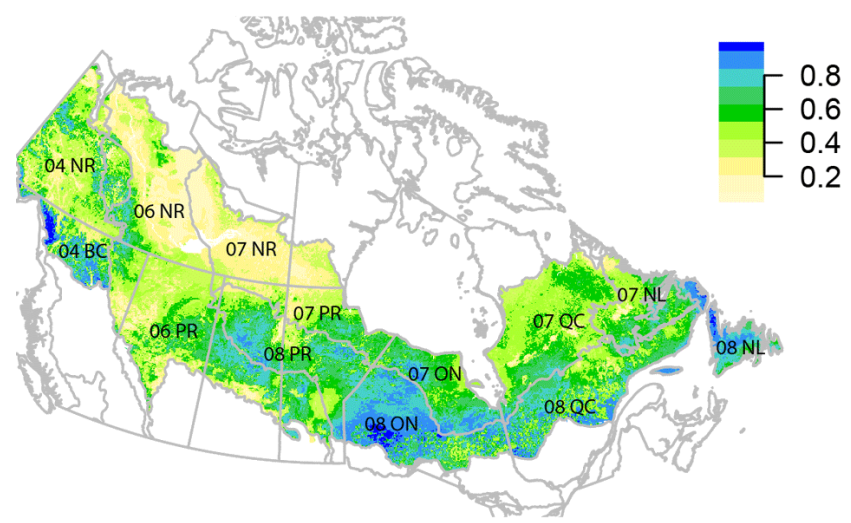

(c) BCR-stratified, diversity-focused

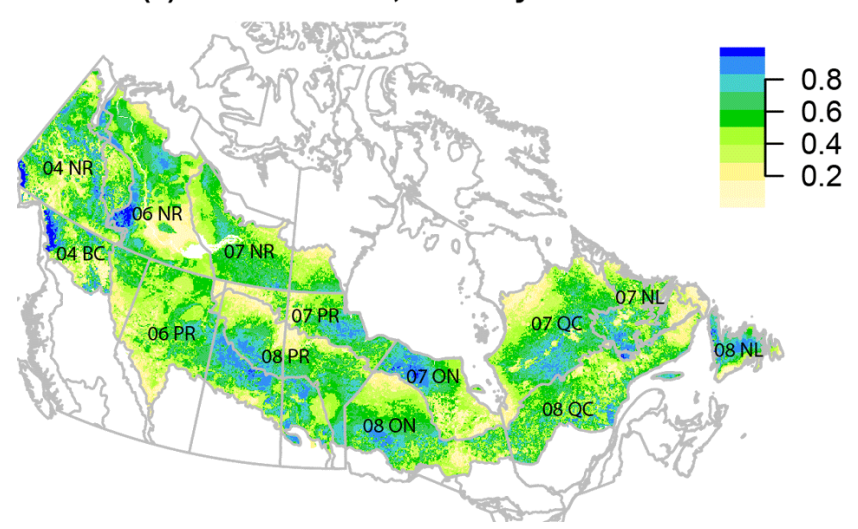

When comparing scenarios based on just future (midcentury) projections with those combining current and future distributions, the difference in Zonation ranking was of similar magnitude, but more consistent across scenarios (Figs. A5.1-2).

Overall, the factor that most influenced priority rankings was climate change, with the difference between current and midcentury climate solutions greater than all other paired factors evaluated (Table 3). The next most influential factor was

\section{(b) boreal-wide, representation-focused}

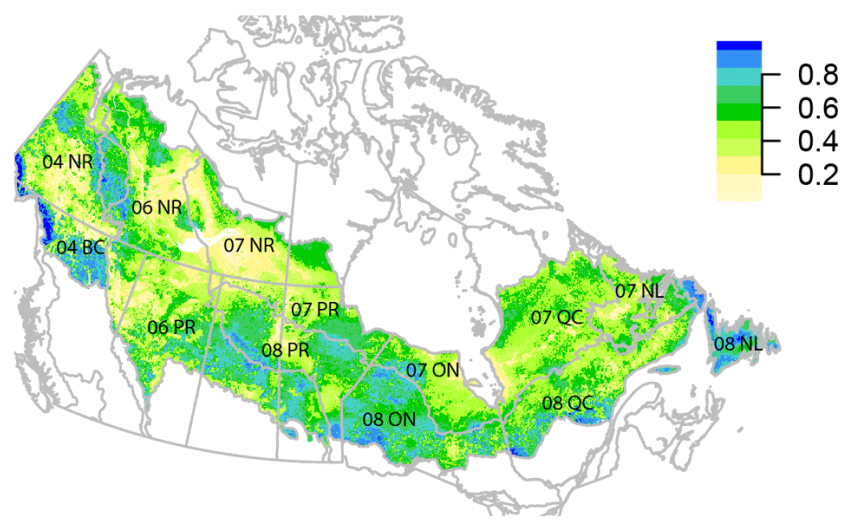

(d) BCR-stratified, representation-focused

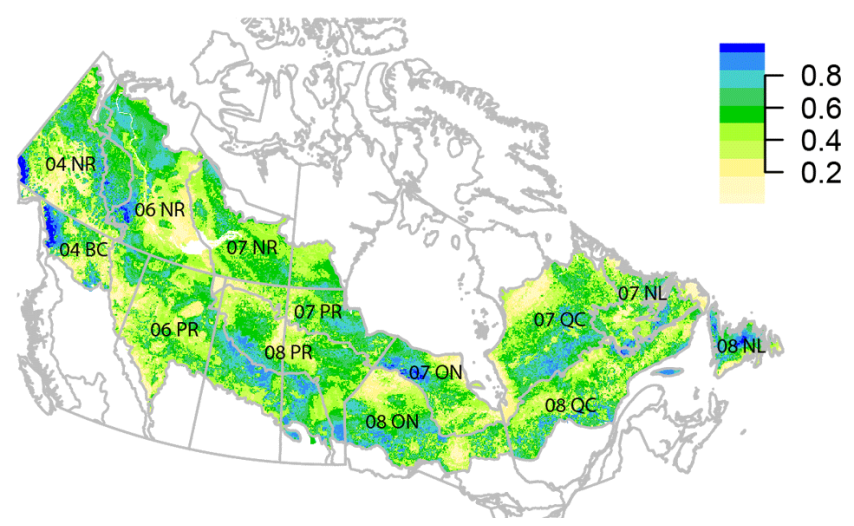

geographic stratification; species weighting by conservation status was least influential (Table 3).

With respect to threshold-independent efficiency, i.e., bird conservation value per unit area, the mean AUC of the scenario performance curves across all scenarios was relatively low $(0.58)$. We did not find great differences across the 64 representationfocused (core area) scenarios, with AUC ranging from 0.54 to 0.63 (mean 0.57 ) of combined bird conservation value (Table A6.1). 
Table 3. Overall scenario factor influence on conservation value. Pairs of scenarios were evaluated by calculating the pixel-level differences in mean priority ranks across all other scenario factors. Values represent mean and standard deviation of pixel-level differences in priority ranks ranging from 0 to 1.

\begin{tabular}{llc}
\hline \hline Scenario Comparison & Factor & Mean $( \pm$ SD) Difference \\
\hline Current vs. future & Climate change and uncertainty & $0.246( \pm 0.178)$ \\
Stratified vs. Boreal & Stratification & $0.145( \pm 0.128)$ \\
Current vs. current/future combo & Climate change and uncertainty & $0.134( \pm 0.114)$ \\
Current/future combo vs. future & Climate change and uncertainty & $0.130( \pm 0.108)$ \\
Uncertainty vs. no uncertainty & Climate change and uncertainty & $0.114( \pm 0.108)$ \\
Species representation vs. diversity & Prioritization algorithm & $0.091( \pm 0.073)$ \\
Disturbance vs. no disturbance & Disturbance & $0.074( \pm 0.118)$ \\
Forest species vs. all species & Species included & $0.058( \pm 0.059)$ \\
Priority weights vs. no weights & Species weights & $0.034( \pm 0.028)$ \\
\hline \hline
\end{tabular}

Fig. 7. Standard deviation for four groups of 32 scenarios: boreal-wide, diversity-focused (a) and representation-focused (b), and bird conservation subregion-stratified diversity-focused (c) and representation-focused (d). Highest variation in Zonation ranks is in red; lowest variation is in light orange. $\mathrm{BCR}=$ bird conservation region.

(a) boreal-wide, diversity-focused

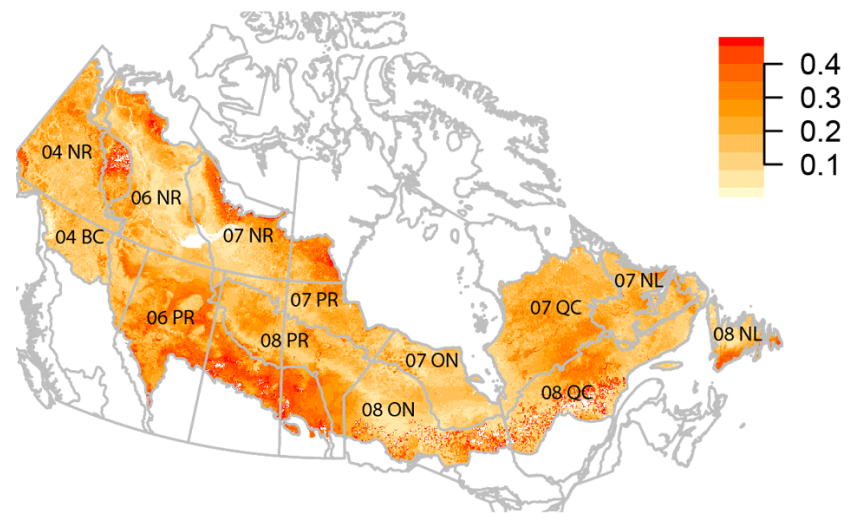

(c) BCR-stratified, diversity-focused

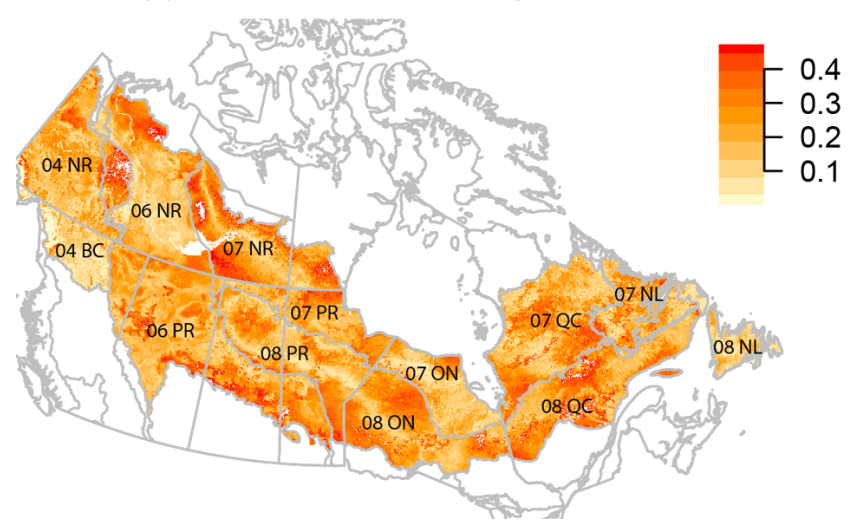

(b) boreal-wide, representation-focused

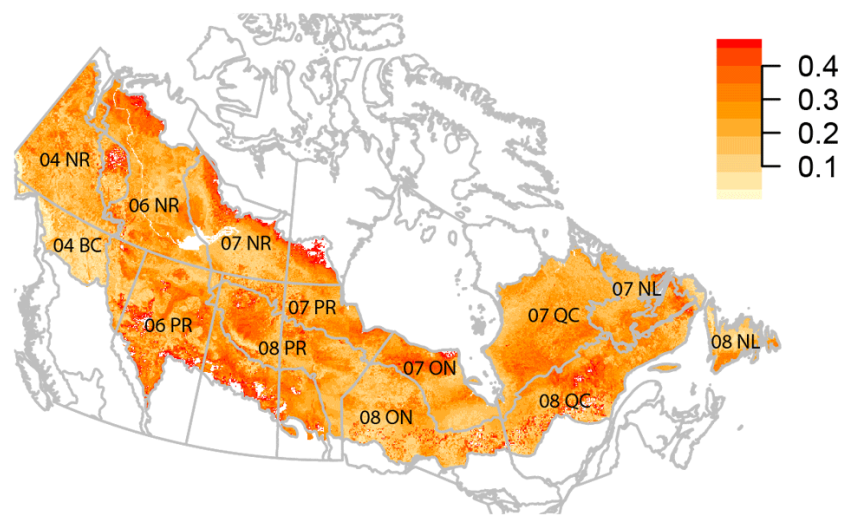

(d) BCR-stratified, representation-focused

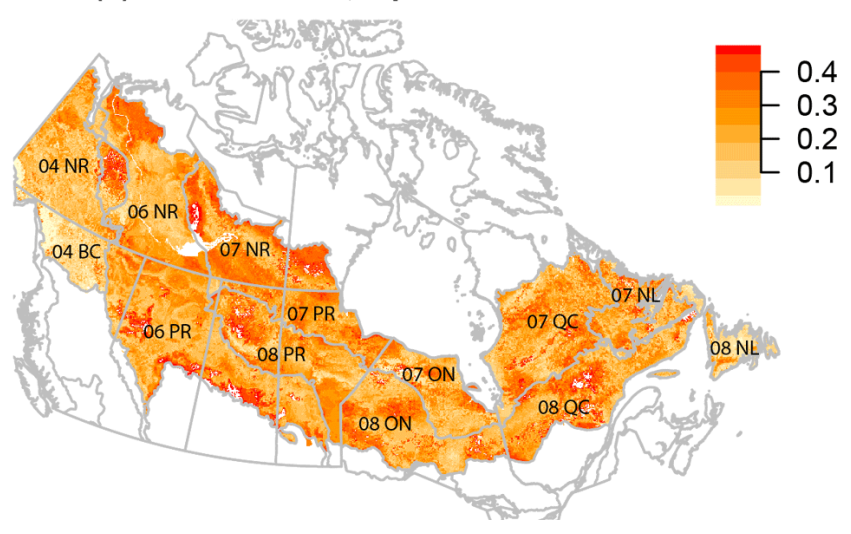

Diversity-focused (additive benefit function) scenarios captured a slightly higher conservation value per unit area, with a mean AUC of 0.59 , ranging from 0.54 to 0.66 (Table A6.1). The most efficient scenarios were those that focused on forest species and included uncertainty and disturbance discounting (Table A6.1). The least efficient scenarios were those that were stratified by bird conservation subregion (Table A6.1). Threshold-independent scenario efficiency varied by species, with generally lower values for wide-ranging species (Table A6.2).

The most efficient land proportion thresholds, in terms of additive efficiency (difference between proportional bird conservation 
Fig. 8. Comparison among (a) baseline boreal-wide, species representation-focused rankings (scenario 1) and sequential influences of (b) disturbance-discounting, (c) forest species and priority weighting, (d) uncertainty discounting, and (e) midcentury climate change, respectively; (f) cumulative solution (scenario 46). Highest Zonation ranks are in dark blue; lowest ranks are in yellow. Blue indicates higher rank than comparison scenario; red indicates lower rank.

(a) Baseline Representation / Boreal-wide

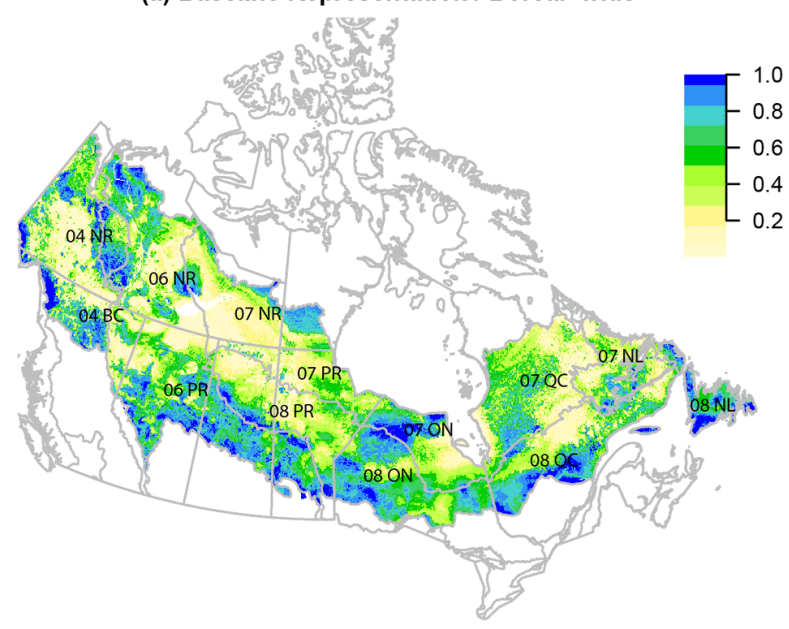

(c) Species and Weighting Difference

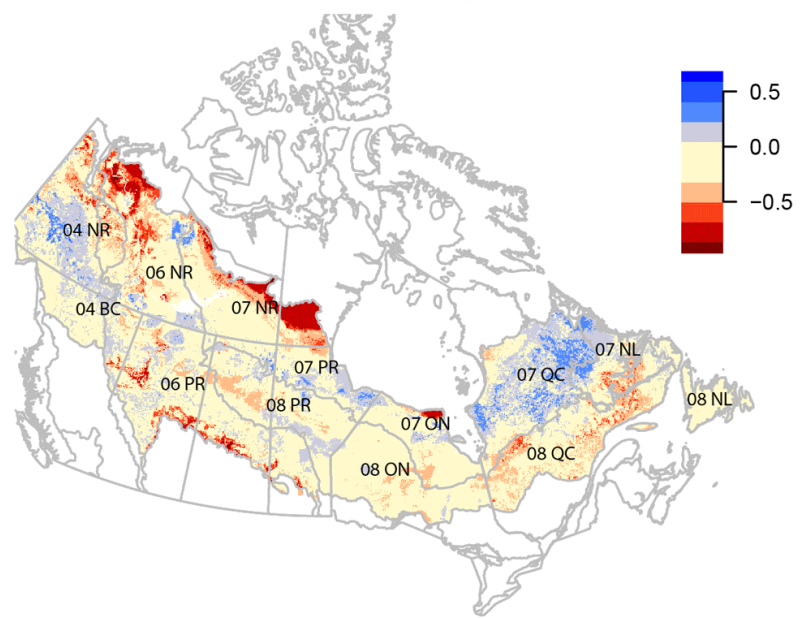

(e) Climate-change Difference

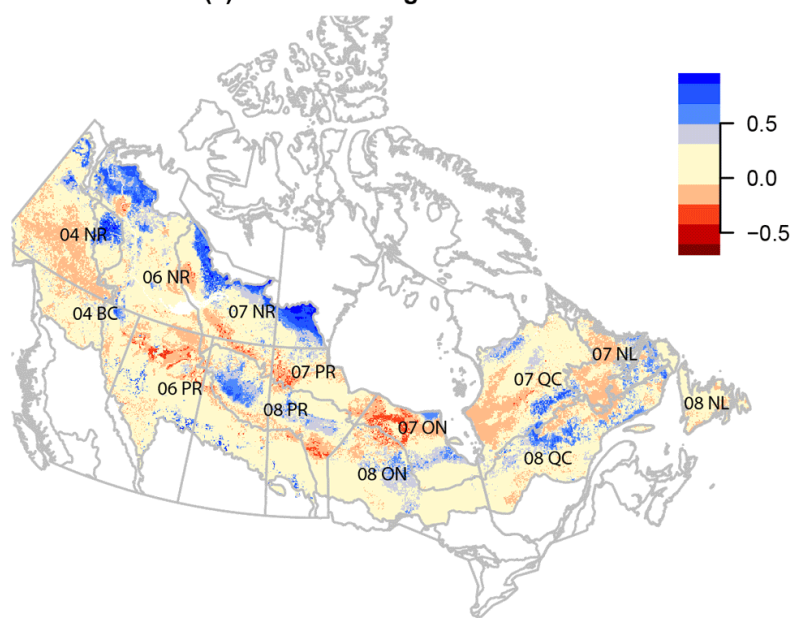

(b) Disturbance-discounting Difference

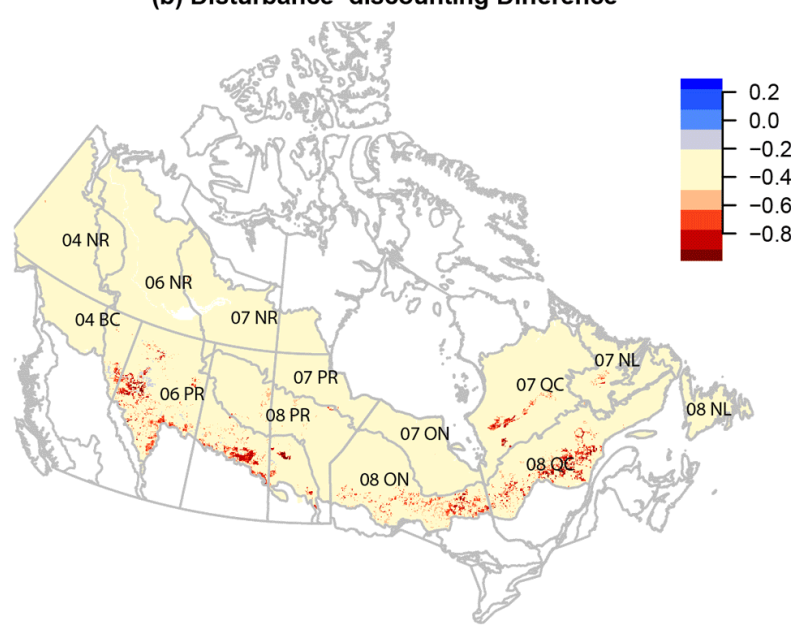

(d) Uncertainty-discounting Difference

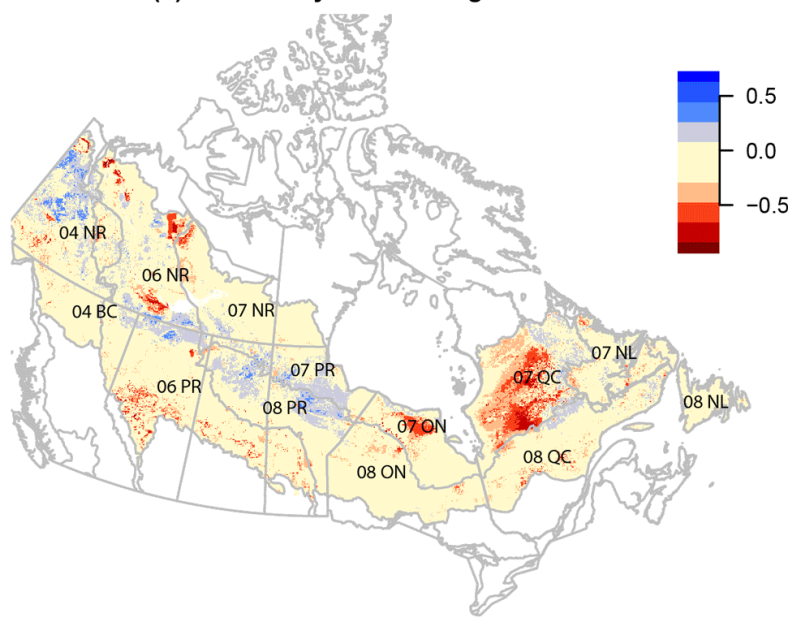

(f) Cumulative Representation / Boreal-wide

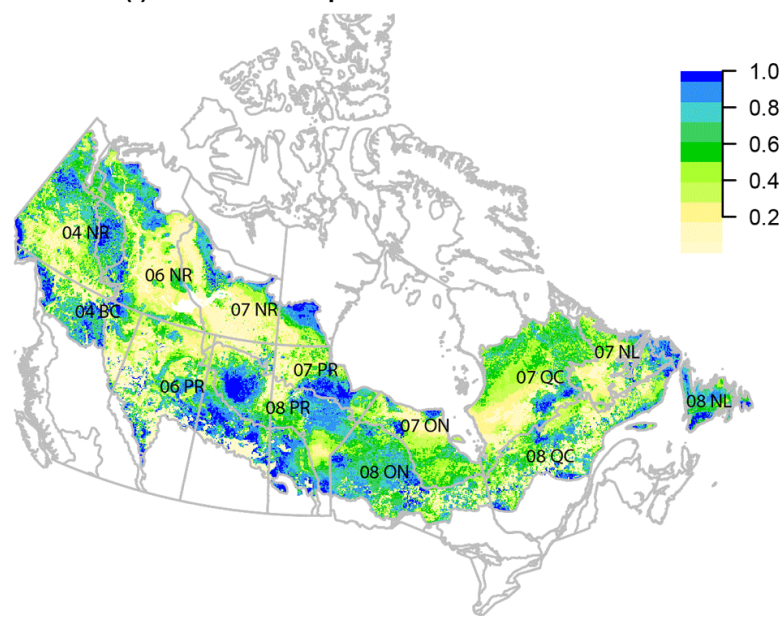


value and proportional land area) ranged from 0.31 to 0.56 , with a mean of 0.44 , corresponding to proportional bird conservation values ranging from 0.36 to 0.66 , with a mean of 0.55 (Fig. 9a). For all scenarios, proportional efficiency (the ratio of bird conservation value to land area) decreased rapidly with land area (Fig. 9b). Overall, the diversity-focused scenarios had higher proportional efficiency values than the representation-focused scenarios (Fig. 9b).

Fig. 9. Performance curves for all 128 scenarios (blue $=$ diversity-focused, red = representation-focused), representing (a) additive efficiency, the weighted average proportion of species conservation value (abundance) conserved by a given proportion of the study region, and (b) proportional efficiency, the ratio of bird conservation value to land area across study region thresholds. Vertical lines indicate study region proportions where additive efficiency, as shown by corresponding horizontal lines, is highest for a given scenario. See Table A6.1 for further details.

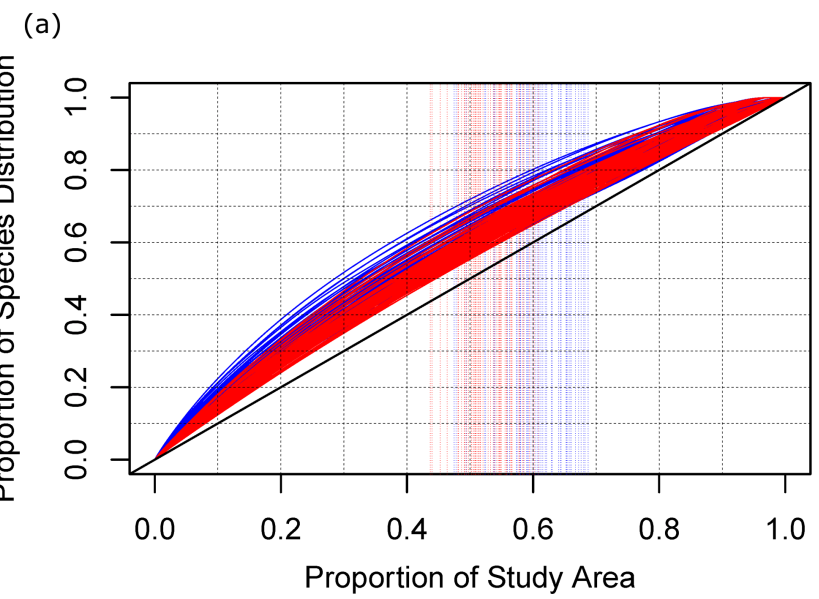

(b)

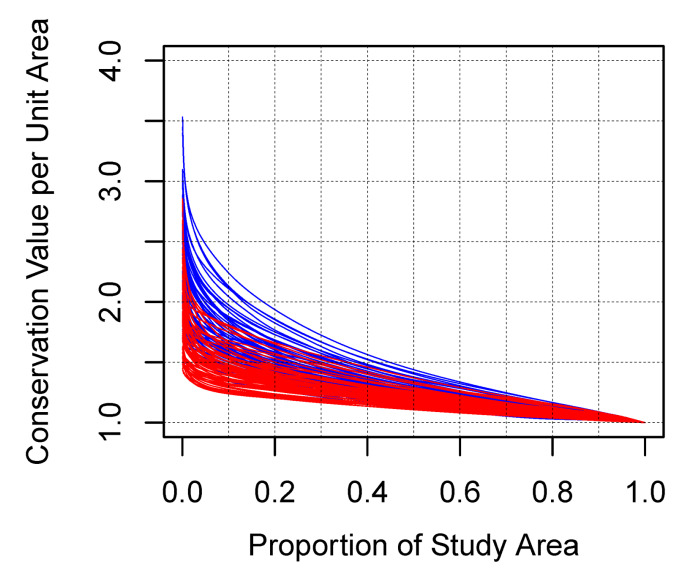

\section{DISCUSSION}

Given the large and low-density distributions of boreal songbirds, as well as the predominantly intact condition of boreal habitats, we did not expect to identify universal conservation hotspots across the scenarios considered. Indeed, we found large differences between solutions depending on constraints and a priori conservation objectives, and relatively low conservation efficiency overall, i.e., proportion of abundance conserved per unit area, consistent with other boreal analyses (Powers et al. 2013), especially for wide-ranging species. This reflects, in part, the relatively undisturbed nature of the Canadian boreal region, with numerous conservation opportunities remaining, and a resulting high level of substitutability among similar areas. In comparison, highly developed regions are likely to exhibit a much larger contrast between high- and low-value areas.

We did, however, find increasing consistency among solutions as multiple constraints and objectives were considered. In particular, the geographic stratification of solutions by BCR subregion resulted in more consistent priorities, although at the expense of efficiency. Other constraints, including climate change, discounting for disturbance and uncertainty, and the selection and weighting of species, helped to further focus priorities. This indicates the importance of applying a roadmap of conservation objectives, such as the framework presented here (Fig. 1), as well as considering as many relevant objectives and constraints as possible. When all scenarios were combined, some consistent high-value areas did emerge, which may be considered as general candidates for implementation of conservation action.

Among the most highly ranked areas were northwestern mountainous regions (British Columbia and the Yukon), where elevational diversity and resulting environmental heterogeneity likely promotes species diversity in both current and future time periods (MacArthur 1964, Veech and Crist 2007). In Newfoundland, similar heterogeneity factors may also have resulted in high rankings across scenarios, in conjunction with maritime conditions that moderate current and future climates resulting in high climate refugia potential (Stralberg et al. 2015b). Finally, both southern and northern portions of Ontario and the Prairie Region (Manitoba and Saskatchewan) were consistently highly ranked. The importance of this central boreal region may stem from areas of high overlap among western and eastern species and a tendency toward highest diversity in the center of a continent, i.e., the mid-domain effect (Colwell and Lees 2000). Northern and southern study region margins are likely important for representation of more marginally distributed species, some of which may have core distributions outside the boreal region. For example, species' southern margins (here reflected by arctic species extending into the northern boreal region) may be particularly important from the standpoint of conserving genetic diversity and enhancing adaptive capacity, despite threats from climate change (Hampe and Petit 2005). Thus, these convergent regions may be considered important from a biogeographical standpoint, i.e., regions with the greatest potential to encompass either many species at once (diversity) and/or uniquely distributed species (representation). They do not necessarily reflect areas of high local diversity, which cannot be discerned at this coarse resolution.

\section{The importance of climate change}

The biggest factor differentiating scenarios was climate change, with shifts in species distributions resulting in distinctive shifts in conservation value. Given the magnitude of future change expected, and the potential loss and degradation of forest throughout much of the study region (Price et al. 2013, Gauthier 
et al. 2015), climate change cannot be ignored as a factor. However, bird conservation plans should not be solely based on projected future distributions because there are substantial uncertainties about responses of vegetation communities to climate change (Price et al. 2013, Stralberg et al. 2015b). Considering future distributions (and associated uncertainty) in conjunction with current distributions provides a reasonable compromise that necessarily moderates predicted future conditions using current conditions. As noted by Runge et al. (2016), this increases the minimum area that must be conserved to achieve a desired level of biodiversity conservation. An alternative approach would be to identify species-specific climate refugia and use those areas as Zonation objectives, thereby increasing efficiency (Stralberg et al. 2015b).

\section{Considering disturbance}

Anthropogenic disturbance is concentrated in the southern portion of our study region, which largely coincides with areas identified as conservation priorities by the species diversityfocused scenarios. This is likely because species diversity is partly driven by energy availability (Mönkkönen et al. 2006, Evans et al. 2008), which is associated with latitude via solar insolation. Given this confluence of disturbance and species diversity, we opted for a localized and conservative treatment of disturbance. Our disturbance-discounting approach effectively excluded highly disturbed areas from Zonation solutions, while still allowing areas of intermediate disturbance to be considered. Consequently, our results are strongly tied to the accuracy and consistency of disturbance information. More specific and extensive delineation of disturbance types could improve the precision of Zonation solutions and eliminate potential spatial biases in solutions. For example, relatively permanent disturbances, e.g., oil and gas infrastructure or agricultural conversion, could be distinguished from arguably more transitional disturbances, such as timber harvest. Although some data to facilitate this distinction are available for a portion of the boreal forest (Pasher et al. 2013), they are not yet available across the full study region. Consequently, we erred on the side of caution, given the potentially long-lasting footprint of many disturbances on the landscape. However, we recognize that the identification of highvalue habitats that have been affected by human activity may be useful for identifying restoration and management priorities. It may also be helpful to consider the potential future rate of development, so as to prioritize areas with high conservation value that are also at high risk in the absence of conservation.

\section{Distribution model limitations and uncertainty}

We recognize that density and distribution models rely on several assumptions, including environmental (vs. biotic) control of a species' distribution, and equilibrium between a species and its environment (Wiens et al. 2009). The ramifications of not meeting those assumptions are greatest in unsampled areas, especially where extrapolation is required (Araújo and Peterson 2012). By discounting for model uncertainty, we underemphasized areas requiring the greatest model extrapolation, thereby decreasing their importance. Yet these may represent some of the greatest opportunities for protection, because sampling tends to follow economic development and associated disturbance. Thus, additional sampling is needed to reduce model uncertainty and provide equal treatment to all areas of the boreal region.
Furthermore, the scale of prediction applied here is relatively coarse $(4 \mathrm{~km})$, and additional work is required to delineate the finer-scale priorities that are important for local and regional planning.

\section{Criteria for an efficient continental solution}

In terms of bird conservation value per unit area, the diversityfocused scenarios yielded more efficient solutions than those based on representation of species' core areas, which tend to be driven by rare species. This is not surprising, given that individual species are essentially interchangeable under the diversity-based objective. Weighting by conservation status also had a positive effect on efficiency scores, by definition, because the efficiency metric consists of weighted species' abundance values. Thus, carefully considered species weights are useful to ensure that solutions reflect conservation objectives.

Scenarios that incorporated disturbance and/or uncertainty were more efficient than those that did not, which is likely because of the fact that the distribution of uncertainty values was similar for most species, and disturbance impacts were assumed equal for all species. Variability in the latter could result in more heterogeneous solutions.

With respect to climate change, our results echoed those of other studies (Carroll et al. 2010, Powers et al. 2017), where including future climate did not improve efficiency, likely because of geographic divergence of species' ranges over time. Similarly, scenarios that were stratified by bird conservation subregion also yielded lower efficiency scores, demonstrating that optimality is lost when solutions are forced to be equally distributed across regions, consistent with findings by Wiersma (2007) for Canadian mammals. This presents trade-offs between efficiency and geographic representation that planners must navigate.

Overall, we found that the highest efficiency, in terms of added bird conservation value, was achieved with land proportions ranging from 0.31 to 0.56 of the total study region. This does not suggest that the corresponding top-ranked areas in any of the scenarios considered provide adequate or necessary habitat for species persistence. However, assuming that population density is a good indicator of habitat quality (Bock and Jones 2004), 0.310.56 may be interpreted as a range of thresholds beyond which returns may be diminishing, in terms of avian conservation value per unit area.

In the end, however, efficiency is just one component of a solution's performance. It may be useful to examine the extent to which reserve networks that emphasize priority bird species also protect population concentrations of other priority taxa, e.g., caribou. Previous results on the surrogacy value of birds for other taxa have been mixed (Rodrigues et al. 1999, Garson et al. 2002, Warman et al. 2004, Franco et al. 2009).

\section{The importance of a priori conservation objectives}

Major differences in Zonation rankings were driven by external factors such as disturbance and climate change, as well as choices regarding prioritization metric and geographic stratification. This highlights the importance of establishing clear, a priori objectives at the outset of a conservation planning exercise, and using these to guide the interpretation of results and identification of 
Avian Conservation and Ecology 13(2): 12

conservation priorities and management strategies. For example, optimal conservation solutions for priority species within a given subregion are very different from boreal-wide solutions focused on areas of highest overall songbird diversity.

Planners and decision makers must take careful account of conservation objectives and policy implications when navigating these decisions. We have provided a framework to identify potential scenarios for passerine bird conservation (Fig. 1), but there will be other management considerations that we have not evaluated. For example, we did not consider future development potential or existing protected areas and reserves in this analysis, nor did we explicitly consider connectivity among new and existing protected areas networks, which may be important considerations (Pouzols et al. 2014). Furthermore, in this ecologically intact region, large-scale opportunities to protect and manage large representative landscapes with active disturbance regimes may outweigh species-driven considerations (Schmiegelow et al. 2014). Nevertheless, our objective, data-driven solutions for passerine birds can also be incorporated into such larger decisionmaking frameworks.

\section{CONCLUSION}

Which areas in the boreal region of Canada provide the highest songbird conservation value? The answer to this question can vary greatly, depending on conservation objectives and constraints. For a given set of criteria, our scenario results can cautiously be used to inform a variety of broad-scale conservation and management efforts, from protected areas planning to species-atrisk recovery to restoration and monitoring. Our systematic and data-driven approach also allows planners to assess the influence of explicit criteria on spatial prioritization. The process of assessing multiple scenarios, each representing an alternative set of conservation objectives, can identify areas that are important across multiple criteria, and also quantify the trade-offs that exist among conservation objectives. Choosing which scenarios to implement leaves the realm of science, and instead is at the discretion of managers, who must thread the needle between available resources, competing objectives, and conservation opportunities.

Responses to this article can be read online at: http://www.ace-eco.org/issues/responses.php/1303

\section{Acknowledgments:}

This paper is a contribution of the Boreal Avian Modelling ( BAM) Project, an international research collaboration on the ecology, management, and conservation of boreal birds. We acknowledge the BAM Project's members, avian and biophysical data partners, and funding agencies (including Environment and Climate Change Canada), listed in full at http://www.borealbirds.calindex.php/ acknowledgements. We are grateful to CWS-ECCC staff Tony Turner, Judith Kennedy, Rachel Vallender, Russ Weeber, and Samuel Haché for guidance, to Trish Fontaine and Alberto SuarezEsteban for help with GIS processing, and to Steve Cumming and two anonymous reviewers for constructive manuscript reviews.

\section{LITERATURE CITED}

Araújo, M. B., and A. T. Peterson. 2012. Uses and misuses of bioclimatic envelope modeling. Ecology 93:1527-1539. http://dx. doi.org/10.1890/11-1930.1

Badiou, P., R. Baldwin, M. Carlson, M. Darveau, P. Drapeau, K. Gaston, J. Jacobs, J. Kerr, S. Levin, M. Manseau, G. Orians, S. Pimm, H. Possingham, P. Raven, F. Reid, D. Roberts, T. Root, N. Roulet, J. Schaefer, D. Schindler, J. Strittholt, N. Turner, and J. Wells. 2013. Conserving the world's last great forest is possible: here's how. International Boreal Conservation Science Panel. [online] URL: http://www.borealscience.org/projects/conservinglast-great-forests/

Barker, N. K. S., S. G. Cumming, and M. Darveau. 2014. Models to predict the distribution and abundance of breeding ducks in Canada. Avian Conservation and Ecology 9(2):7. http://dx.doi. org/10.5751/ACE-00699-090207

Barker, N. K. S., P. C. Fontaine, S. G. Cumming, D. Stralberg, A. Westwood, E. M. Bayne, P. Sólymos, F. K. A. Schmiegelow, S. J. Song, and D. J. Rugg. 2015. Ecological monitoring through harmonizing existing data: lessons from the boreal avian modelling project. Wildlife Society Bulletin 39:480-487. http://dx. doi.org/10.1002/wsb.567

Bird Studies Canada and NABCI. 2014. Bird conservation regions. Bird Studies Canada on behalf of the North American Bird Conservation Initiative, Port Rowan, Ontario, Canada. [online] URL: http://www.birdscanada.org/research/gislab/index.jsp?targetpg= bcr

Bock, C. E., and Z. F. Jones. 2004. Avian habitat evaluation: should counting birds count? Frontiers in Ecology and the Environment 2:403-410. http://dx.doi.org/10.1890/1540-9295 (2004)002[0403:AHESCB]2.0.CO;2

Bradshaw, C. J. A., I. G. Warkentin, and N. S. Sodhi. 2009. Urgent preservation of boreal carbon stocks and biodiversity. Trends in Ecology \& Evolution 24:541-548. http://dx.doi.org/10.1016/j. tree.2009.03.019

Brandt, J. P. 2009. The extent of the North American boreal zone. Environmental Reviews 17:101-161. http://dx.doi.org/10.1139/ A09-004

Canadian Forest Service. 2015. Canadian national fire database. Natural Resources Canada, Canadian Forest Service, Northern Forestry Centre, Edmonton, Alberta, Canada. [online] URL: http://cwfis.cfs.nrcan.gc.ca/ha/nfdb

Carlson, M. 2015. Prioritization of landbird habitat in Canada's boreal and hemiboreal region. Report to Canadian Wildlife Service. Environment and Climate Change Canada, Ottawa, Canada.

Carlson, M., J. Wells, and D. Roberts. 2009. The carbon the world forgot: conserving the capacity of Canada's boreal forest region to mitigate and adapt to climate change. Boreal Songbird Initiative, Seattle, Washington, USA, and Canadian Boreal Initiative, Ottawa, Ontario, Canada. [online] URL: https://www. borealbirds.org/publications/carbon-world-forgot-conserving-capacitycanadas-boreal-forest-region-mitigate-and-adapt 
Carroll, C., J. R. Dunk, and A. Moilanen. 2010. Optimizing resiliency of reserve networks to climate change: multispecies conservation planning in the Pacific Northwest, USA. Global Change Biology 16:891-904. http://dx.doi.org/10.1111/ j.1365-2486.2009.01965.x

Colwell, R. K., and D. C. Lees. 2000. The mid-domain effect: geometric constraints on the geography of species richness. Trends in Ecology \& Evolution 15:70-76. http://dx.doi.org/10.1016/ S0169-5347(99)01767-X

Commission for Environmental Cooperation (CEC). 1997. Ecological regions of North America: toward a common perspective. Montréal, Québec, Canada.

Csuti, B., S. Polasky, P. H. Williams, R. L. Pressey, J. D. Camm, M. Kershaw, A. R. Kiester, B. Downs, R. Hamilton, M. Huso, and K. Sahr. 1997. A comparison of reserve selection algorithms using data on terrestrial vertebrates in Oregon. Biological Conservation 80:83-97. http://dx.doi.org/10.1016/S0006-3207(96) 00068-7

Cumming, S. G., K. Lefevre, E. Bayne, T. Fontaine, F. K. A. Schmiegelow, and S. J. Song. 2010. Toward conservation of Canada's boreal forest avifauna: design and application of ecological models at continental extents. Avian Conservation and Ecology 5(2):8. http://dx.doi.org/10.5751/ACE-00406-050208

Dinerstein, E., D. Olson, A. Joshi, C. Vynne, N. D. Burgess, E. Wikramanayake, N. Hahn, S. Palminteri, P. Hedao, R. Noss, M. Hansen, H. Locke, E. C. Ellis, B. Jones, C. V. Barber, R. Hayes, C. Kormos, V. Martin, E. Crist, W. Sechrest, L. Price, J. E. M. Baillie, D. Weeden, K. Suckling, C. Davis, N. Sizer, R. Moore, D. Thau, T. Birch, P. Potapov, S. Turubanova, A. Tyukavina, N. de Souza, L. Pintea, J. C. Brito, O. A. Llewellyn, A. G. Miller, A. Patzelt, S. A. Ghazanfar, J. Timberlake, H. Klöser, Y. ShennanFarpón, R. Kindt, J.-P. B. Lillesø, P. van Breugel, L. Graudal, M. Voge, K. F. Al-Shammari, and M. Saleem. 2017. An ecoregionbased approach to protecting half the terrestrial realm. BioScience 67:534-545. http://dx.doi.org/10.1093/biosci/bix014

Early, R., B. Anderson, and C. D. Thomas. 2008. Using habitat distribution models to evaluate large-scale landscape priorities for spatially dynamic species. Journal of Applied Ecology 45:228-238. http://dx.doi.org/10.1111/j.1365-2664.2007.01424.x

Elith, J., C. H. Graham, R. P. Anderson, M. Dudik, S. Ferrier, A. Guisan, R. J. Hijmans, F. Huettmann, J. R. Leathwick, A. Lehmann, J. Li, L. G. Lohmann, B. A. Loiselle, G. Manion, C. Moritz, M. Nakamura, Y. Nakazawa, J. McC. M. Overton, A. Townsend Peterson, S. J. Phillips, K. Richardson, R. ScachettiPereira, R. E. Schapire, J. Soberón, S. Williams, M. S. Wisz, and N. E. Zimmermann. 2006. Novel methods improve prediction of species' distributions from occurrence data. Ecography 29:129-151. http://dx.doi.org/10.1111/j.2006.0906-7590.04596.x

Elith, J., J. R. Leathwick, and T. Hastie. 2008. A working guide to boosted regression trees. Journal of Animal Ecology 77:802-813. http://dx.doi.org/10.1111/j.1365-2656.2008.01390.x

Evans, K. L., S. E. Newson, D. Storch, J. J. D. Greenwood, and K. J. Gaston. 2008. Spatial scale, abundance and the speciesenergy relationship in British birds. Journal of Animal Ecology 77:395-405. http://dx.doi.org/10.1111/j.1365-2656.2007.01332.x
Franco, A. M. A., B. J. Anderson, D. B. Roy, S. Gillings, R. Fox, A. Moilanen, and C. D. Thomas. 2009. Surrogacy and persistence in reserve selection: landscape prioritization for multiple taxa in Britain. Journal of Applied Ecology 46:82-91. http://dx.doi. org/10.1111/j.1365-2664.2008.01598.x

Garson, J., A. Aggarwal, and S. Sarkar. 2002. Birds as surrogates for biodiversity: an analysis of a data set from southern Québec. Journal of Biosciences 27:347-360. http://dx.doi.org/10.1007/ BF02704965

Gauthier, S., P. Bernier, T. Kuuluvainen, A. Z. Shvidenko, and D. G. Schepaschenko. 2015. Boreal forest health and global change. Science 349:819-822. http://dx.doi.org/10.1126/science.aaa9092

Hampe, A., and R. J. Petit. 2005. Conserving biodiversity under climate change: the rear edge matters. Ecology Letters 8:461-467. http://dx.doi.org/10.1111/j.1461-0248.2005.00739.x

Hansen, M. C., P. V. Potapov, R. Moore, M. Hancher, S. A. Turubanova, A. Tyukavina, D. Thau, S. V. Stehman, S. J. Goetz, T. R. Loveland, A. Kommareddy, A. Egorov, L. Chini, C. O. Justice, and J. R. G. Townshend. 2013. High-resolution global maps of 21st-century forest cover change. Science 342:850-853. http://dx.doi.org/10.1126/science. 1244693

Krawchuk, M., K. Lisgo, S. Leroux, P. Vernier, S. Cumming, and F. Schmiegelow. 2012. Boreal forest, Canada. Pages 69-79 in J. A. Hilty, C. C. Chester, and M. S. Cross, editors. Climate and conservation: landscape and seascape science, planning, and action. Island Press, Washington, D.C., USA. http://dx.doi. org/10.5822/978-1-61091-203-7_6

Kukkala, A. S., and A. Moilanen. 2013. Core concepts of spatial prioritisation in systematic conservation planning. Biological Reviews 88:443-464. http://dx.doi.org/10.1111/brv.12008

Lehtomäki, J., E. Tomppo, P. Kuokkanen, I. Hanski, and A. Moilanen. 2009. Applying spatial conservation prioritization software and high-resolution GIS data to a national-scale study in forest conservation. Forest Ecology and Management 258:2439-2449. http://dx.doi.org/10.1016/j.foreco.2009.08.026

Leroux, S. J., and F. K. A. Schmiegelow. 2007. Biodiversity concordance and the importance of endemism. Conservation Biology 21:266-268. http://dx.doi.org/10.1111/j.1523-1739.2006.00628. $\mathrm{x}$

Leroux, S. J., F. K. A. Schmiegelow, R. B. Lessard, and S. G. Cumming. 2007. Minimum dynamic reserves: a framework for determining reserve size in ecosystems structured by large disturbances. Biological Conservation 138:464-473. http://dx.doi. org/10.1016/j.biocon.2007.05.012

MacArthur, R. H. 1964. Environmental factors affecting bird species diversity. American Naturalist 98:387-397. http://dx.doi. org/10.1086/282334

Magness, D. R., A. L. Sesser, and T. Hammond. 2018. Using topographic geodiversity to connect conservation lands in the Central Yukon, Alaska. Landscape Ecology 33:547-556. http://dx. doi.org/10.1007/s10980-018-0617-0

Margules, C. R., A. O. Nicholls, and R. L. Pressey. 1988. Selecting networks of reserves to maximise biological diversity. Biological Conservation 43:63-76. http://dx.doi.org/10.1016/0006-3207(88) 90078-X 
Moilanen, A. 2007. Landscape Zonation, benefit functions and target-based planning: unifying reserve selection strategies. Biological Conservation 134:571-579. http://dx.doi.org/10.1016/j. biocon.2006.09.008

Moilanen, A., B. J. Anderson, F. Eigenbrod, A. Heinemeyer, D. B. Roy, S. Gillings, P. R. Armsworth, K. J. Gaston, and C. D. Thomas. 2011. Balancing alternative land uses in conservation prioritization. Ecological Applications 21:1419-1426. http://dx. doi.org/10.1890/10-1865.1

Moilanen, A., F. M. Pouzols, L. Meller, V. Veach, A. Arponen, J. Leppänen, and H. Kujala. 2014. Zonation version 4 user manual. Biodiversity Conservation Informatics Group, Department of Biosciences, University of Helsinki, Helsinki, Finland.

Mönkkönen, M., J. T. Forsman, and F. Bokma. 2006. Energy availability, abundance, energy-use and species richness in forest bird communities: a test of the species-energy theory. Global Ecology and Biogeography 15:290-302. http://dx.doi.org/10.1111/ j.1466-8238.2006.00224.x

Pasher, J., E. Seed, and J. Duffe. 2013. Development of boreal ecosystem anthropogenic disturbance layers for Canada based on 2008 to 2010 Landsat imagery. Canadian Journal of Remote Sensing 39:42-58. http://dx.doi.org/10.5589/m13-007

Pickett, S. T. A., and J. N. Thompson. 1978. Patch dynamics and the design of nature reserves. Biological Conservation 13:27-37. http://dx.doi.org/10.1016/0006-3207(78)90016-2

Pouzols, F. M., and A. Moilanen. 2014. A method for building corridors in spatial conservation prioritization. Landscape Ecology 29:789-801. http://dx.doi.org/10.1007/s10980-014-0031-1

Pouzols, F. M., T. Toivonen, E. Di Minin, A. S. Kukkala, P. Kullberg, J. Kuusterä, J. Lehtomäki, H. Tenkanen, P. H. Verburg, and A. Moilanen. 2014. Global protected area expansion is compromised by projected land-use and parochialism. Nature 516:383-386. http://dx.doi.org/10.1038/nature14032

Powers, R. P., N. C. Coops, T. Nelson, M. A. Wulder, and C. Ronnie Drever. 2013. Integrating accessibility and intactness into large-area conservation planning in the Canadian boreal forest. Biological Conservation 167:371-379. http://dx.doi.org/10.1016/j. biocon.2013.08.032

Powers, R. P., N. C. Coops, V. J. Tulloch, S. E. Gergel, T. A. Nelson, and M. A. Wulder. 2017. A conservation assessment of Canada's boreal forest incorporating alternate climate change scenarios. Remote Sensing in Ecology and Conservation 3:202-216. http://dx. doi.org/10.1002/rse2.34

Pressey, R. L., and A. O. Nicholls. 1989. Efficiency in conservation evaluation: scoring versus iterative approaches. Biological Conservation 50:199-218. http://dx.doi.org/10.1016/0006-3207 (89)90010-4

Pressey, R. L., H. P. Possingham, and J. R. Day. 1997. Effectiveness of alternative heuristic algorithms for identifying indicative minimum requirements for conservation reserves. Biological Conservation 80:207-219. http://dx.doi.org/10.1016/ S0006-3207(96)00045-6

Price, D. T., R. I. Alfaro, K. J. Brown, M. D. Flannigan, R. A. Fleming, E. H. Hogg, M. P. Girardin, T. Lakusta, M. Johnston, D. W. McKenney, J. H. Pedlar, T. Stratton, R. N. Sturrock, I. D.
Thompson, J. A. Trofymow, and L. A. Venier. 2013. Anticipating the consequences of climate change for Canada's boreal forest ecosystems. Environmental Reviews 21:322-365. http://dx.doi. org/10.1139/er-2013-0042

Rodrigues, A. S. L., R. Tratt, B. D. Wheeler, and K. J. Gaston. 1999. The performance of existing networks of conservation areas in representing biodiversity. Proceedings of the Royal Society of London. Series B: Biological Sciences 266:1453. http://dx.doi. org/10.1098/rspb.1999.0800

Rondinini, C., and F. Chiozza. 2010. Quantitative methods for defining percentage area targets for habitat types in conservation planning. Biological Conservation 143:1646-1653. http://dx.doi. org/10.1016/j.biocon.2010.03.037

Rosenberg, K. V., J. A. Kennedy, R. Dettmers, R. P. Ford, D. Reynolds, J. D. Alexander, C. J. Beardmore, P. J. Blancher, R. E. Bogart, G. S. Butcher, A. F. Camfield, A. Couturier, D. W. Demarest, R. Dettmers, W. E. Easton, R. P. Ford, J. J. Giocomo, R. H. Keller, J. A. Kennedy, A. E. Mini, A. O. Panjabi, D. N. Pashley, T. D. Rich, J. M. Ruth, H. Stabins, J. Stanton, and T. Will. 2016. Partners in Flight Landbird Conservation Plan: 2016 revision for Canada and Continental United States. Partners in Flight Science Committee. [online] URL: https://www. partnersinflight.org/what-we-do/science/plans/

Runge, M. C., J. C. Stroeve, A. P. Barrett, and E. McDonaldMadden. 2016. Detecting failure of climate predictions. Nature Climate Change 6:861-864. http://dx.doi.org/10.1038/nclimate3041

Schindler, D. W., and P. G. Lee. 2010. Comprehensive conservation planning to protect biodiversity and ecosystem services in Canadian boreal regions under a warming climate and increasing exploitation. Biological Conservation 143:1571-1586. http://dx.doi.org/10.1016/j.biocon.2010.04.003

Schmiegelow, F. K. A., S. G. Cumming, K. A. Lisgo, S. J. Leroux, and M. A. Krawchuk. 2014. Catalyzing large landscape conservation in Canada's boreal systems: the BEACONs project experience. Pages 97-122 in J. N. Levitt, editor. Conservation catalysts. Lincoln Institute of Land Policy, Cambridge, Massachusetts, USA.

Slattery, S. M., J. L. Morrisette, G. G. Mack, and E. W. Butterworth. 2011. Waterfowl conservation planning: science needs and approaches. Pages 23-40 in J. V. Wells, editor. Boreal birds of North America: a hemispheric view of their conservation links and significance. Studies in Avian Biology 41. University of California Press, Berkeley, California, USA.

Solomon, M., A. S. Van Jaarsveld, H. C. Biggs, and M. H. Knight. 2003. Conservation targets for viable species assemblages? Biodiversity \& Conservation 12:2435-2441. http://dx.doi. org/10.1023/A:1025805731366

Sólymos, P., S. M. Matsuoka, E. M. Bayne, S. R. Lele, P. Fontaine, S. G. Cumming, D. Stralberg, F. K. A. Schmiegelow, and S. J. Song. 2013. Calibrating indices of avian density from nonstandardized survey data: making the most of a messy situation. Methods in Ecology and Evolution 4:1047-1058. http://dx.doi. org/10.1111/2041-210X.12106

Stralberg, D., E. M. Bayne, S. G. Cumming, P. Sólymos, S. J. Song, and F. K. A. Schmiegelow. 2015b. Conservation of future boreal forest bird communities considering lags in vegetation response 
to climate change: a modified refugia approach. Diversity and Distributions 21:1112-1128. http://dx.doi.org/10.1111/ddi.12356

Stralberg, D., S. M. Matsuoka, A. Hamann, E. M. Bayne, P. Sólymos, F. K. A. Schmiegelow, X. Wang, S. G. Cumming, and S. J. Song. 2015a. Projecting boreal bird responses to climate change: the signal exceeds the noise. Ecological Applications 25:52-69. http://dx.doi.org/10.1890/13-2289.1

Summers, D. M., B. A. Bryan, N. D. Crossman, and W. S. Meyer. 2012. Species vulnerability to climate change: impacts on spatial conservation priorities and species representation. Global Change Biology 18:2335-2348. http://dx.doi.org/10.1111/j.1365-2486.2012.02700. $\mathrm{x}$

Svancara, L. K., R. Brannon, J. M. Scott, C. R. Groves, R. F. Noss, and R. L. Pressey. 2005. Policy-driven versus evidencebased conservation: a review of political targets and biological needs. BioScience 55:989-995. http://dx.doi.org/10.1641/0006-3568 (2005)055[0989:PVECAR]2.0.CO;2

Tear, T. H., P. Kareiva, P. L. Angermeier, P. Comer, B. Czech, R. Kautz, L. Landon, D. Mehlman, K. Murphy, M. Ruckelshaus, J. M. Scott, and G. Wilhere. 2005. How much is enough? The recurrent problem of setting measurable objectives in conservation. BioScience 55:835-849. http://dx.doi.org/10.1641/0006-3568 (2005)055[0835:HMIETR]2.0.CO;2

Veech, J. A., and T. O. Crist. 2007. Habitat and climate heterogeneity maintain beta-diversity of birds among landscapes within ecoregions. Global Ecology and Biogeography 16:650-656. http://dx.doi.org/10.1111/j.1466-8238.2007.00315.x

Veloz, S., L. Salas, B. Altman, J. Alexander, D. Jongsomjit, N. Elliott, and G. Ballard. 2015. Improving effectiveness of systematic conservation planning with density data. Conservation Biology 29:1217-1227. http://dx.doi.org/10.1111/cobi.12499

Warman, L. D., D. M. Forsyth, A. R. E. Sinclair, K. Freemark, H. D. Moore, T. W. Barrett, R. L. Pressey, and D. White. 2004. Species distributions, surrogacy, and important conservation regions in Canada. Ecology Letters 7:374-379. http://dx.doi. org/10.1111/j.1461-0248.2004.00590.x

Wells, J., and P. Blancher. 2011. Global role for sustaining bird populations. Pages 7-22 in J. Wells, editor. Boreal birds of North America: a hemispheric view of their conservation links and significance. Studies in Avian Biology 41. University of California Press, Berkeley, California, USA.

Wiens, J. A., D. Stralberg, D. Jongsomjit, C. A. Howell, and M. A. Snyder. 2009. Niches, models, and climate change: assessing the assumptions and uncertainties. Proceedings of the National Academy of Sciences of the United States of America 106:19729-19736. http://dx.doi.org/10.1073/pnas.0901639106

Wiersma, Y. F. 2007. The effect of target extent on the location of optimal protected areas networks in Canada. Landscape Ecology 22:1477-1487. http://dx.doi.org/10.1007/s10980-007-9126-2
Wiersma, Y. F., and T. D. Nudds. 2006. Conservation targets for viable species assemblages in Canada: are percentage targets appropriate? Biodiversity \& Conservation 15:4555-4567. http://dx. doi.org/10.1007/s10531-005-5819-5

Wiersma, Y. F., and D. J. H. Sleep. 2018. The effect of target setting on conservation in Canada's boreal: what is the right amount of area to protect? Biodiversity and Conservation 27:733-748. http:// dx.doi.org/10.1007/s10531-017-1461-2

Wiersma, Y. F., D. J. H. Sleep, and K. A. Edwards. 2017. Scientific evidence for fifty percent? BioScience 67:781-782. http://dx.doi. org/10.1093/biosci/bix067

Williams, P., D. Gibbons, C. Margules, A. Rebelo, C. Humphries, and R. Pressey. 1996. A comparison of richness hotspots, rarity hotspots, and complementary areas for conserving diversity of British birds. Conservation Biology 10:155-174. http://dx.doi. org/10.1046/j.1523-1739.1996.10010155.x
Editor-in-Chief: Keith A.Hobson

Subject Editor: Steven GCumming
Sponsored by the Society of Canadian Ornithologists and Bird Studies Canada Parrainée par la Société des ornithologistes $d u$ Canada et Études d'oiseaux Canada

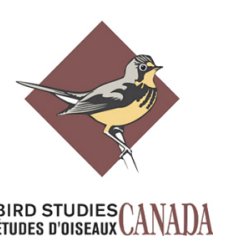


Appendix 1. Scenarios and inputs

Please click here to download file 'appendix1.pdf'. 
Avian Conservation and Ecology 13(2): 12

http://www.ace-eco.org/vol13/iss2/art12/

Appendix 2. Priority rankings for representation-based scenarios

Please click here to download file 'appendix2.pdf'. 
Avian Conservation and Ecology 13(2): 12

http://www.ace-eco.org/vol13/iss2/art12/

Appendix 3. Priority rankings for diversity-based scenarios

Please click here to download file 'appendix3.pdf'. 
Avian Conservation and Ecology 13(2): 12

http://www.ace-eco.org/vol13/iss2/art12/

Appendix 4. Sequential ranking comparisons

Please click here to download file 'appendix4.pdf'. 
Avian Conservation and Ecology 13(2): 12

http://www.ace-eco.org/vol13/iss2/art12/

Appendix 5. Climate change scenarios

Please click here to download file 'appendix5.pdf'. 
Avian Conservation and Ecology 13(2): 12

http://www.ace-eco.org/vol13/iss2/art12/

Appendix 6. Scenario efficiency results

Please click here to download file 'appendix6.pdf'. 